\title{
TGF- $\beta$ Signaling Protects Retinal Neurons from Programmed Cell Death during the Development of the Mammalian Eye
}

\author{
Barbara M. Braunger, ${ }^{1}$ Stefan Pielmeier, ${ }^{1}$ Cora Demmer, ${ }^{1}$ Victoria Landstorfer, ${ }^{1}$ Daniela Kawall, ${ }^{1}$ Natalie Abramov, ${ }^{1}$ \\ Marco Leibinger, ${ }^{2}$ Ingo Kleiter, ${ }^{3}$ Dietmar Fischer, ${ }^{2}$ Herbert Jägle, ${ }^{4}$ and Ernst R. Tamm ${ }^{1}$ \\ ${ }^{1}$ Institute of Human Anatomy and Embryology, University of Regensburg, D-93053 Regensburg, Germany, ${ }^{2}$ Department of Neurology, Experimental \\ Neurology, Heinrich-Heine-University Düsseldorf, D-40225 Düsseldorf, Germany, ${ }^{3}$ Department of Neurology, St. Josef-Hospital, D-44791 Bochum, \\ Germany, and ${ }^{4}$ Department of Ophthalmology, University of Regensburg, D-93053 Regensburg, Germany
}

We investigated the influence of transforming growth factor- $\beta$ (TGF- $\beta$ ) signaling on developmental programmed cell death in the mouse retina by direct and specific molecular targeting of TGF- $\beta$ type II receptor (T $\beta$ RII) and Smad7 in retinal progenitor cells. Mice were generated carrying a conditional deletion of the T $\beta$ RII in cells that originate from the inner layer of the optic cup. The animals showed a significant decrease of phosphorylated Smad3 in both the central and peripheral retina, which indicates the diminished activity of TGF- $\beta$ signaling. T $\beta$ RII deficiency significantly increased the apoptotic death of retinal neurons during embryonic and postnatal development without affecting their proliferation. In contrast, treatment with TGF- $\beta 2$ inhibited cell death of retinal ganglion cells in dissociated retinal cell cultures, an effect that was blocked by inhibiting the phosphorylation of Smad3. The increase in apoptosis during development resulted in a significant reduction in the number of neurons in adult T $\beta$ RII-deficient mice. The effect was most pronounced in the inner retina neurons and resulted in functional deficits as determined by electroretinography. In contrast, a conditional deletion of TGF- $\beta$ inhibiting Smad7 in retinal neurons significantly enhanced Smad3 phosphorylation and significantly decreased apoptosis of retinal neurons in embryos and pups. Moreover, the number of retinal ganglion cells was significantly higher in Smad7-deficient mice compared with control littermates. T $\beta$ RII-deficient pups showed a lower level of nerve growth factor (NGF) in its mRNA; however, higher levels were observed in Smad7-deficient pups, which strongly suggests that the protective effects of TGF- $\beta$ signaling on developmental cell death are mediated through NGF.

\section{Introduction}

Developmental programmed cell death occurs in basically all major subtypes of neurons and, depending on the region and the cell type, up to $70 \%$ of developed neurons do not survive to adulthood (Oppenheim, 1991; Yeo and Gautier, 2004; Buss et al., 2006). In the retina of the avian eye, programmed cell death of neuronal progenitors is under the control of nerve growth factor (NGF), which is released from microglia to act on progenitors that express the neurotrophin receptor p75 (p75NTR) and not TrkA (Frade and Barde, 1998a). NGF induces cell death upon binding to p75, which is pro-apoptotic in the absence of TrkA (Frade and Barde, 1998b; Nykjaer et al., 2005). The role of NGF/ p75 signaling in mammalian retina development is less clear. A

Received March 5, 2013; revised June 30, 2013; accepted July 30, 2013.

Author contributions: E.R.T. designed research; B.M.B., S.P., C.D., V.L., D.K., N.A., M.L., D.F., and H.J. performed research; I.K. contributed unpublished reagents/analytic tools; B.M.B., S.P., C.D., V.L., D.K., N.A., M.L., D.F., H.J., and E.R.T. analyzed data; B.M.B. and E.R.T. wrote the paper.

This work is funded by the Deutsche Forschungsgemeinschaft Grant FOR 1075 (TP5). We thank Silvia Babl, Angelika Pach, Margit Schimmel, and Elke Stauber for excellent technical assistance.

The authors declare no competing financial interests.

Correspondence should be addressed to Ernst R. Tamm, Institute of Human Anatomy and Embryology, University of Regensburg, Universitätsstr. 31, D-93053 Regensburg, Germany. E-mail: ernst.tamm@vkl.uni-regensburg.de.

DOI:10.1523/JNEUROSCI.0991-13.2013

Copyright $\odot 2013$ the authors $\quad 0270-6474 / 13 / 3314246-13 \$ 15.00 / 0$ significant reduction in the number of apoptotic progenitors occurs during early embryonic development of p75-deficient retinae (Frade and Barde, 1999; Harada et al., 2006). Nevertheless, this scenario does not result in obvious changes in the retinal morphology of p75-deficient mice past embryonic day 15 (E15; Harada et al., 2006).

In addition, transforming growth factor (TGF)- $\beta$ signaling modulates the cell death of progenitors in the avian retina. Accordingly, the application of antibodies that neutralize the signaling of TGF- $\beta$ isoforms (TGF- $\beta 1$, TGF- $\beta 2$, and TGF- $\beta 3$ ) results in reduced apoptosis of progenitors and an increase in retinal thickness in treated embryos, and these effects appear to be independent of NGF/p75 signaling (Dünker et al., 2001). The relevance of these findings regarding the development of the mammalian retina is unclear. Embryos of double TGF- $\beta 2 / T G F-$ $\beta 3$-deficient mice show a reduction of progenitors undergoing programmed cell death at E14.5 (Dünker and Krieglstein, 2003), but they die at approximately E15.5, a time when programmed cell death of retinal progenitors has reached its peak and well before death of more differentiated retinal neurons begins (Young, 1984; Farah and Easter, 2005).

TGF- $\beta$ signaling involves binding to the type II transmembrane receptor (T $\beta$ RII), a serine/threonine kinase that assembles 
Table 1. Antibodies used for Western blot analysis

\begin{tabular}{lll}
\hline Primary antibody & Blocking & Secondary antibody \\
\hline T $\beta$ RII-c16 (Santa Cruz Biotechnology) 1:200 & $5 \%$ non-fat dry milk & Chicken anti-rabbit coupled to horseradish peroxidase (Santa Cruz Biotechnology); 1:2000 \\
pSmad3 (Abcam) 1:200 & $5 \%$ BSA & Chicken anti-rabbit coupled to horseradish peroxidase (Santa Cruz Biotechnology); 1:2000 \\
pSmad3 (Cell Signaling Technology) 1:200 & $5 \%$ BSA & Chicken anti-rabbit coupled to horseradish peroxidase (Santa Cruz Biotechnology); 1:2000 \\
Smad7 (Santa Cruz Biotechnology) 1:200 & $5 \%$ BSA & Chicken anti-goat coupled to horseradish peroxidase (Santa Cruz Biotechnology); 1:2000 \\
NGF (Alomone Labs) 1:250 & $3 \%$ BSA & Chicken anti-rabbit coupled to horseradish peroxidase (Santa Cruz Biotechnology) 1:2000 \\
\hline
\end{tabular}

with the type I receptor (T $\beta$ RI; ALK5). T $\beta$ RI becomes phosphorylated and activated, and in turn phosphorylates the downstream effectors Smad2 and Smad3, which then form a complex with Smad4. The complex translocates into the nucleus to interact with various transcription factors causing the activation of specific target genes. The inhibitory Smad7 interferes with TGF- $\beta$ signaling and appears to play an essential role in the autoinhibitory negative feedback regulation of canonical TGF- $\beta$ signaling (Yan et al., 2009).

Herein, we investigated the influence of TGF- $\beta$ signaling on developmental programmed cell death in the mouse retina by direct and specific molecular targeting of T $\beta$ RII and Smad7 in retinal neurons and Müller glia. Hence, we generated mutant mice with a conditional downregulation or upregulation of TGF- $\beta$ signaling by deleting T $\beta$ RII or Smad7 in cells that originate from the inner layer of the optic cup. We provide evidence for an important neuroprotective role of TGF- $\beta$ signaling during the development of the mammalian retina. The neuroprotective effects involve increased Smad3 phosphorylation and may be mediated through the neurotrophic activities of NGF.

\section{Materials and Methods}

Mice. All procedures conformed to the tenets of the National Institutes of Health Guidelines on the Care and Use of Animals in Research, the EU Directive, 2010/63/E, and institutional guidelines. All experiments were performed in mice of either sex. Mice carrying two unrecombined $T g f b r 2^{f l / f l}$ alleles (Chytil et al., 2002; Ito et al., 2003) or two unrecombined Smad $7^{f l f l}$ alleles (Kleiter et al., 2010) were crossed with Tgfbr $2^{f l / f l} ; \alpha$-Cre or $S m a d f^{f l f l} ; \alpha$-Cre mice that were each heterozygous for transgenic $\alpha$-Cre (Marquardt et al., 2001). Resulting Tgfbr $2^{f l f l} ; \alpha$-Cre or Smad7 ${ }^{f l / f l}$; $\alpha$-Cre mice had recombined and inactivated Tgfbr $2^{f l / f l}$ or $S m a d 7^{f l / f l}$ alleles in the neural retina cells that originate from the inner layer of the optic cup and were used as experimental mice. $\alpha$-Cre-negative littermates with two unrecombined Tgfbr $2^{f l f l}$ or $S m a d f^{f l f l}$ alleles were used as control mice. Genetic backgrounds were 129SV (Tgfbr2), C57BL/6 (Smad7), or FVB-N ( $\alpha$-Cre). Embryos were obtained from timed matings with noon of the day of vaginal plug discovery designated as $0.5 \mathrm{~d}$ of gestation (E0.5). The day of birth was referred to as P0. All mice were reared in $12 \mathrm{~h}$ light/dark cycles (lights on at 7:00 A.M.). Genotypes were screened by isolating genomic DNA from tail biopsies and testing for transgenic sequences by PCR. For Cre-PCR analysis primers were as follows: $5^{\prime}-\mathrm{CA}$ CCCTGTTACGTAAGC-3' (sense) and 5'-CTAATCGCCATCTTCC AG-3' (antisense). The thermal cycle profile was denaturation at $96^{\circ} \mathrm{C}$ for $30 \mathrm{~s}$, annealing at $57^{\circ} \mathrm{C}$ for $30 \mathrm{~s}$, and extension at $72^{\circ} \mathrm{C}$ for $1 \mathrm{~min}$ for 35 cycles. For genotyping of Tgfbr $2^{f l f l}$ animals, primers were $5^{\prime}$-GCAGGC ATCAGGACCCAGTTTGATCC-3' (sense) and 5'-AGAGTGAAGCCG TGGTAGGTGAGCTTG-3' (antisense), and for Smad $7^{f l / f l}$ primers were 5'-GTCAGGTTGGATCACCATGCC-3' (sense) and 5' -ACTGCCTGGA GAAGTGTGTCG-3' (antisense). For both, the thermal cycle profile included denaturation at $96^{\circ} \mathrm{C}$ for $30 \mathrm{~s}$, annealing at $61^{\circ} \mathrm{C}$ for $30 \mathrm{~s}$, and extension at $72^{\circ} \mathrm{C}$ for $1 \mathrm{~min}$ for 35 cycles.

Tgfbr2 deletion PCR. Whole retinae were isolated and folded in half, with the optic nerve head located at the top of the semicircle. Next, the retinae were dissected into three pieces (central, intermediate, and peripheral) of equal size according to the schematic drawing in Figure $1 A$. DNA was extracted from each sample, and Tgfbr2 deletion PCR was performed. Deletion primers were 5'-TAAACAAGGTCCGGAGCC
CA-3' (sense) and 5'AGAGTGAAGCCGTGGTAGGTGAGCTTG-3' (antisense) (Chytil et al., 2002). The thermal cycle profile was denaturation at $96^{\circ} \mathrm{C}$ for $30 \mathrm{~s}$, annealing at $62^{\circ} \mathrm{C}$ for $1 \mathrm{~min}$, and extension at $72^{\circ} \mathrm{C}$ for $1 \mathrm{~min}$ for 35 cycles. Actin was used as the loading control.

Western blot analysis. Retinal proteins were isolated following the manufacturer's instructions (Invitrogen) for TRIzol protein isolation. Proteins used in NGF Western blots were separated by Urea-PAGE (4/3 $16 \%$ acrylamide $+6 \mathrm{~m}$ Urea), while other proteins were separated by SDS-PAGE (10\% gels) and transferred by semidry blotting onto a polyvinyl difluoride membrane (PVDF; Millipore). For NGF dot blot analysis, proteins were applied onto slots of a Minifold-SRC96-Dot blot device (Schleicher and Schüll) and transferred onto a PVDF membrane via vacuum filtration. PVDF membranes were incubated with Tris-buffered saline (TBS) containing 0.1\% Tween 20 (PBST; pH 7.2) and blocking reagent (Table 1) overnight. Antibodies were used as described in Table 1. After washing with TBS-T, secondary antibodies (1:2000) were added. Chemiluminescence was detected on a LAS 3000 imaging workstation. For normalization, blots were labeled with antibodies against glyceraldehyde 3-phosphate dehydrogenase (GAPDH, 1:10,000, horseradish peroxidase-conjugated, Abcam), while dot blots were stained with Coomassie blue. Western blot and dot blot signals were evaluated by relative densitometry with the Aida Image Analyzer v.4.06 software (Raytest).

Light microscopy. Eyes of experimental and control mice were enucleated at different embryonic and postnatal days (E12.5, E14.5, E16.5, P5, P10, P15, P20, 6 weeks, and 3 and 6 months). Eyes and optic nerves were fixed for $24 \mathrm{~h}$ in $2 \%$ paraformaldehyde (PFA) $/ 2.5 \%$ glutaraldehyde (Karnovsky, 1965) and embedded in Epon (Serva) as previously described (Kritzenberger et al., 2011). Semithin sagittal sections (1.0 $\mu \mathrm{m}$ thick) were cut through the eyes and stained according to the protocol by Richardson et al. (1960) Cross semithin sections through the optic nerve were stained with paraphenylenediamine (PPD) to visualize myelinated axons as previously described (Kroeber et al., 2010). Thickness of the outer (ONL) or inner (INL) nuclear layers was measured on semithin sections along the mid-horizontal (nasotemporal) plane. The distance between ora serrata (OS) and optic nerve head (ONH) was divided into tenths and measured between each tenth (Hao et al., 2002; Braunger et al., 2013). For quantification of optic nerve axons, the total number of PPD-labeled axons in optic nerve cross sections was counted (Kroeber et al., 2010). The total number of neuronal nuclei in the ganglion cell layer was counted per mid-sagittal section.

Immunohistochemistry. Eyes were fixed for $4 \mathrm{~h}$ in $4 \%$ PFA, washed extensively in phosphate buffer (PP, $0.1 \mathrm{M})$, and embedded in paraffin according to standard protocols. Sections $(6.0 \mu \mathrm{m})$ were deparaffinized and washed in $\mathrm{H}_{2} \mathrm{O}$. For detection of T $\beta$ RII and pSmad3, sections were treated with boiling citrate buffer $(1 \times 10 \mathrm{~min}, \mathrm{pH} 6)$, washed again in $\mathrm{H}_{2} \mathrm{O}$, and incubated in $0.1 \mathrm{M} \mathrm{PP}$. For bromodeoxyuridine (BrdU)labeling of E 16.5 embryos, their mother was injected with $200 \mu \mathrm{l}$ of 5-bromo-2'-deoxyuridine ( $10 \mathrm{mg} / \mathrm{ml}$ in PBS, i.p.) $2 \mathrm{~h}$ before Cesarean section. Heads of embryos were fixed in 4\% PFA overnight and bisected along the mid-sagittal plane before embedding in paraffin. Sections were treated with $0.05 \mathrm{M}$ Tris- $\mathrm{HCl}$ ( $5 \mathrm{~min})$, covered with Proteinase K $(100 \mu \mathrm{l}$ of Proteinase $\mathrm{K}$ in $57 \mathrm{ml}$ Tris $-\mathrm{HCl}(0.05 \mathrm{M}), 5 \mathrm{~min})$, washed in $\mathrm{H}_{2} \mathrm{O}$, incubated in $1 \mathrm{~N} \mathrm{HCl}(30 \mathrm{~min})$, and washed again in $\mathrm{H}_{2} \mathrm{O}$. Sections were incubated in PP for $5 \mathrm{~min}$. For immunohistochemistry, paraffin sections were washed three times in TBS (pSmad3) or PP (others) for 5 min each and blocked with $5 \%$ nonfat dry milk (BrdU) or $2 \%$ bovine serum albumin (others) in PP/TBS for $45 \mathrm{~min}$ at room temperature. Primary antibodies (Table 2) were diluted in a 1:10 dilution of blocking solution in $\mathrm{PP} / \mathrm{TBS}$ and were incubated at $4^{\circ} \mathrm{C}$ overnight. After three washes in PP/ 
Table 2. Antibodies used for immunohistochemistry

\begin{tabular}{lll}
\hline Primary antibody & Fixation & Secondary antibody \\
\hline T $\beta$ RIII-L21 (Santa Cruz Biotechnology) 1:20 & $4 \%$ PFA & Anti-rabbit, biotinylated (Vector) 1:500, Streptavidin Alexa 488 (Invitrogen) 1:1000 \\
pSmad3 (Cell Signaling Technology) 1:20 & $4 \%$ PFA & Anti-rabbit, biotinylated (Vector) 1:500, Streptavidin Alexa 488 (Invitrogen) 1:1000 \\
BRDU (Invitrogen) 1:50 & $4 \%$ PFA & Horse anti-mouse, biotinylated (Vector) 1:500, Streptavidin Alexa 555 (Invitrogen) 1:1000 \\
$\beta$ III-tubulin (Babco) 1:2000 & $4 \%$ PFA, methanol & Goat anti-mouse IgG Alexa 488 (Invitrogen) 1:1000 \\
Calbindin (Sigma) 1:500 & $4 \%$ PFA & Anti-mouse, biotinylated (Vector) 1:500, Streptavidin Alexa 546 (Invitrogen) 1:1000 \\
Pax6 (Eugentex) 1:50 & $4 \%$ PFA & Anti-rabbit, biotinylated (Vector) 1:500, Streptavidin Alexa 546 (Invitrogen) 1:1000 \\
Calretinin (Swant) 1:400 & $4 \%$ PFA & Anti-rabbit, biotinylated (Vector) 1:200, Streptavidin Alexa 546 (Invitrogen) 1:1000 \\
\hline
\end{tabular}

TBS ( 5 min each), biotinylated secondary antibodies diluted by 1:10 in the blocking solution were applied for $1 \mathrm{~h}$, and then Streptavidin diluted by 1:10 in the blocking solution was applied for $1 \mathrm{~h}$. Sections were washed again three times and counterstained with DAPI (Vectashield; Vector Laboratories) diluted in 1:10 fluorescent mounting medium (Dako). The number of BrdU-positive cell nuclei, calretinin-positive cells, and calbindin-positive cells were counted and normalized to the area of the retina (BrdU) or retinal layers (calretinin and calbindin), which was measured using Axiovision software 3.0 (Carl Zeiss).

Apoptosis. Apoptotic cell death was analyzed by terminal deoxynucleotidyl transferase-mediated dUTP nick end labeling using the Apoptosis Detection System (DeadEnd Fluorometric TUNEL; Promega). In addition, Cell Death Detection ELISA (Roche Diagnostics) was used, which determines histone-associated DNA fragments (mononucleosomes and oligonucleosomes) in the cytoplasmatic fraction of cell lysates. Paraffin sections were investigated following the manufacturer's instructions and previously reported protocols (Seitz et al., 2010; Sippl et al., 2011). For quantitative analysis, the number of TUNEL-positive nuclei in midsagittal sections throughout the entire retina was counted and normalized to the area of the retina that was measured using Axiovision software 3.0 (Carl Zeiss).

Electroretinography. Mice were dark adapted for at least $12 \mathrm{~h}$ before experiments and were anesthetized by subcutaneous injection of ketamine $(65 \mathrm{mg} / \mathrm{kg})$ and xylazine $(13 \mathrm{mg} / \mathrm{kg})$. Pupils were dilated with tropicamide eye drops (Mydriaticum Stulln; Pharma Stulln). Silver needle electrodes served as a reference (forehead) and a ground (tail), and gold wire ring electrodes served as active electrodes. Corneregel (Bausch \& Lomb) was applied to keep the eye hydrated and to maintain good electrical contact. Electroretinograms (ERGs) were recorded using a Ganzfeld bowl (Ganzfeld QC450 SCX; Roland Consult) and an amplifier and recording unit (RETI-Port; Roland Consult). ERGs were recorded from both eyes simultaneously, bandpass filtered (1-300 Hz), and averaged. Single flash scotopic (dark-adapted) responses to a series of 10 LED-flash intensities ranging from -3.5 to $1.0 \log \mathrm{cd} . \mathrm{s} / \mathrm{m}^{2}$ with an interstimulus interval of 2-20 s for the highest intensity were recorded. For the evaluation of temporal characteristics, responses to flickering stimuli with an intensity of $0.5 \log \mathrm{cd} . \mathrm{s} / \mathrm{m}^{2}$ and frequencies ranging from 4 to 25 $\mathrm{Hz}$ were recorded. After $10 \mathrm{~min}$ of adaptation to white background illumination $\left(25 \mathrm{~cd} / \mathrm{m}^{2}\right)$, single flash photopic (light-adapted) responses to three Xenon-flash intensities $\left(1,2\right.$, and $\left.3 \log \mathrm{cd} . \mathrm{s} / \mathrm{m}^{2}\right)$ as well as responses to flickering stimuli (intensity $1.0 \mathrm{log} \mathrm{cd} . \mathrm{s} / \mathrm{m}^{2}$ ) with frequencies ranging from 4 to $25 \mathrm{~Hz}$ were recorded. The scotopic threshold responses (STR), elicited by very weak white flashes (flash intensities: $-4.05,-3.70$, and $-3.53 \log \mathrm{cd} . \mathrm{s} / \mathrm{m}^{2}$ ), were recorded after dark adaptation for $16 \mathrm{~h}$. Oscillatory potentials were extracted from higher intensity waveforms recorded under dark-adapted conditions by bandpass filtering (100-300 $\mathrm{Hz}$ ). For flicker response waveforms, a fast Fourier transform was used to calculate the response magnitude and phase and estimate signal significance. All analysis and plotting was performed with R 2.15.2 (The R Foundation for Statistical Computing) and ggplot2 0.9.3 (Wickham, 2009).

Cell culture. Tissue culture plates (4-well plates; Nunc) were coated with poly-D-lysine $(0.1 \mathrm{mg} / \mathrm{ml}$, molecular weight $<300 \mathrm{kDa}$; Sigma), rinsed three times with distilled water, and then air dried. For culturing of postnatal retinal cells, newborn mice $(\mathrm{C} 57 \mathrm{BL} / 6 \mathrm{j})$ where killed by cervical dislocation. The retinae were rapidly dissected from the eyecups and digested at $37^{\circ} \mathrm{C}$ for $30 \mathrm{~min}$ in DMEM (Invitrogen) containing papain
(16.4 U/ml; Worthington) and L-cysteine ( $0.3 \mu \mathrm{g} / \mathrm{ml}$; Sigma). They were then rinsed with DMEM and triturated in $1.5 \mathrm{ml}$ of DMEM containing B27 (Invitrogen) (1:50) and penicillin/streptomycin (Biochrom, 1:50). Dissociated cells were then passed through a cell strainer ( $40 \mu \mathrm{m}$; Falcon) and $300 \mu \mathrm{l}$ of cell suspension was added to each well. TGF- $\beta 2$ was applied to the medium at $10 \mathrm{ng} / \mathrm{ml}$. In several wells, we additionally applied the inhibitor of Smad3 phosphorylation SIS3 (Calbiochem) at a final concentration of $2.5 \mu \mathrm{M}$ or $7 \mu \mathrm{M}$. The investigator was blinded to the arrangement and the identity of the cultures to prevent the introduction of bias to the analysis. After $2 \mathrm{~h}$ or $24 \mathrm{~h}$ in culture, the cells were fixed with PFA (4\%) and methanol (Sigma). Retinal cultures were then immunocytochemically stained with a $\beta$ III-tubulin-antibody (Babco; 1:2000). To evaluate the survival of retinal ganglion cells following each treatment, the total number of $\beta$ III-tubulin-positive cells with an intact nucleus (DAPI) per well was quantified under a fluorescent microscope $(200 \times)$. The data are denoted as the mean \pm SEM four replicate wells in three independent experiments. RGC-5 cells were cultured in DMEM containing $10 \%$ fetal bovine serum and $1 \%$ penicillin/streptomycin and were maintained in a humidified $37^{\circ} \mathrm{C}$ incubator with $5 \% \mathrm{CO}_{2}$. Before TGF- $\beta 2$ treatment, cells were differentiated with $1 \mu \mathrm{M}$ staurosporine (from Streptomyces staurosporeus; $98 \%$ or greater purity; Alexis Biochemicals) for $1 \mathrm{~h}$ to induce a neuronal phenotype. After staurosporine treatment, cells were cultured in serum-free medium for $12 \mathrm{~h}$ followed by $1 \mathrm{ng} / \mathrm{ml}$ TGF- $\beta 2,3 \mathrm{ng} / \mathrm{ml}$ TGF- $\beta 2$, or $3 \mathrm{ng} / \mathrm{ml}$ TGF- $\beta 2 / 1 \mu \mathrm{M}$ SIS3 incubation for $24 \mathrm{~h}$.

RNA analysis. Total RNA from neural retinae was extracted using TRIzol, and first-strand cDNA synthesis was performed using iScript cDNA Synthesis Kit (Bio-Rad) according to manufacturer's instructions. Quantitative real-time RT-PCR analyses were performed using the BioRad iQ5 Real-Time PCR Detection System. The temperature profile involved denaturation at $95^{\circ} \mathrm{C}$ for $10 \mathrm{~s}$ and annealing and extension at $60^{\circ} \mathrm{C}$ for $40 \mathrm{~s}$ for 40 cycles. All primer pairs were purchased from Invitrogen and extended over exon-intron boundaries except for Gapdh. The sequences of primer pairs, melting temperatures, and PCR product sizes are shown in Table 3. RNA that was not reverse transcribed served as negative control for real-time RT-PCR. Before relative quantification, three different potential housekeeping genes were tested: Gapdh, guanine nucleotide binding protein (Gnb2l), and ribosomal protein L32 (Rpl32). After statistical evaluation of the different housekeepers, Gapdh was used as the housekeeping gene for the relative quantification of retinae samples, and Rpl32 was used for the relative quantification of RGC-5 cells. Quantification was performed using Bio-Rad iQ5 Standard-Edition (Version 2.0.148.60623) software.

Statistical analysis. All results are expressed as the mean \pm SEM. Comparisons between the mean variables of two groups were conducted using the two-tailed Student's $t$ test; $p$ values $\leq 0.05$ were considered to be statistically significant. The significance of the intergroup difference was evaluated using a one-way ANOVA test, followed by corrections for multiple post hoc tests (Bonferroni-Holm, Tukey).

\section{Results}

\section{Conditional deletion of T $\beta$ RII in optic cup-derived cells of} the neural retina

Mixed Tgfbr $2^{f l f l} ; \alpha$-Cre mice were generated that were expected to carry conditionally inactivated Tgfbr 2 alleles in the cells of the neural retina that originate from the inner layer of the optic cup. 
Table 3. Primers used for real-time PCR amplification

\begin{tabular}{|c|c|c|c|c|}
\hline Gene & Sequence & Position & TM & Product size \\
\hline \multirow[t]{2}{*}{ Smad7 } & $5^{\prime}$-acccccatcaccttagtcg $-3^{\prime}$ & $2172-2190$ & 59 & 75 bp \\
\hline & $5^{\prime}$-gaaaatccattgggtatctgga $-3^{\prime}$ & $2225-2246$ & 60 & \\
\hline \multirow{2}{*}{ Fn1 } & $5^{\prime}$-cggagagagtgcccctacta $-3^{\prime}$ & $4218-4237$ & 59 & 77 bp \\
\hline & $5^{\prime}$-cgatattggtgaatcgcaga $-3^{\prime}$ & $4275-4294$ & 59 & \\
\hline \multirow[t]{2}{*}{ Ctgf } & $5^{\prime}$ - tgacctggaggaaaacattaaga-3' & 1013-1035 & 59 & $112 b p$ \\
\hline & $5^{\prime}$-agccctgtatgtcttcacactg $-3^{\prime}$ & $1103-1124$ & 59 & \\
\hline \multirow[t]{2}{*}{ Gapdh } & $5^{\prime}$-tgtccgtcgtggatctgac $-3^{\prime}$ & $763-781$ & 60 & 75 bp \\
\hline & $5^{\prime}-\operatorname{cctgcttcaccaccttcttg}-3^{\prime}$ & $818-837$ & 60 & \\
\hline \multirow[t]{2}{*}{ Gnb2l } & $5^{\prime}$-tctgcaagtacacggtccag $-3^{\prime}$ & $514-533$ & 59 & $88 \mathrm{bp}$ \\
\hline & $5^{\prime}$-acgatgatagggttgctgct $-3^{\prime}$ & $582-601$ & 59 & \\
\hline \multirow[t]{2}{*}{ Rpl32 } & $5^{\prime}$-gctgccatctgttttacgg $-3^{\prime}$ & $29-47$ & 59 & $98 \mathrm{bp}$ \\
\hline & $5^{\prime}$ - gactggtgcctgatgaact $-3^{\prime}$ & $107-126$ & 59 & \\
\hline \multirow[t]{2}{*}{$\mathrm{Ngf}$} & $5^{\prime}$-tatactggccgcagtgaggt-3' & $276-286 / 140-159$ & 60 & $109 \mathrm{bp}$ \\
\hline & $5^{\prime}$-ggacattgctatctgtgtacgg-3' & $354-375 / 227-248$ & 59 & \\
\hline \multirow[t]{2}{*}{ Bdnf } & $5^{\prime}$-agtctccaggacagcaaagc $-3^{\prime}$ & $614-633$ & 59 & $94 \mathrm{bp}$ \\
\hline & $5^{\prime}$-tgcaaccgaagtatgaaataacc $-3^{\prime}$ & $685-707$ & 60 & \\
\hline \multirow[t]{2}{*}{ Ntf3 } & $5^{\prime}$-cgacgtccctggaaatagtc $-3^{\prime}$ & $252-271$ & 59 & 77 bp \\
\hline & $5^{\prime}$-tggacatcacttgttcacct $-3^{\prime}$ & $308-328$ & 60 & \\
\hline \multirow[t]{2}{*}{ Fgf2 } & $5^{\prime}$-cggctctactgcaagaacg $-3^{\prime}$ & $285-303$ & 59 & $108 \mathrm{bp}$ \\
\hline & $5^{\prime}$-tgcttggagttgtagtttgacg $-3^{\prime}$ & $371-392$ & 60 & \\
\hline \multirow[t]{2}{*}{ Gdnf } & $5^{\prime}$-tccaactgggggtctacg $-3^{\prime}$ & $72-89$ & 59 & $77 \mathrm{bp}$ \\
\hline & $5^{\prime}$-gacatcccataacttcatcttagagtc $-3^{\prime}$ & $122-148$ & 59 & \\
\hline \multirow[t]{2}{*}{ Edn2 } & $5^{\prime}$-acctcctccgaaagctgag $-3^{\prime}$ & $502-520$ & 59 & 76 bp \\
\hline & $5^{\prime}$-tttcttgtcacctctggctgta $-3^{\prime}$ & $556-577$ & 59 & \\
\hline \multirow[t]{2}{*}{ Vegfa } & $5^{\prime}$-aaaaacgaaagcgcaagaaa $-3^{\prime}$ & $1470-1489$ & 60 & $73 \mathrm{bp}$ \\
\hline & $5^{\prime}$-tttctccgctctgaacaagg $-3^{\prime}$ & $1523-1542$ & 60 & \\
\hline \multirow[t]{2}{*}{ Lif } & $5^{\prime}$-aaacggcctgcatctaagg $-3^{\prime}$ & $172-190$ & 60 & $93 \mathrm{bp}$ \\
\hline & $5^{\prime}$-agcagcagtaagggcacaat $-3^{\prime}$ & $245-264$ & 59 & \\
\hline \multirow[t]{2}{*}{ Cntf } & $5^{\prime}$-ttgattccacaggcacaaaa-3' & $42-61$ & 60 & 62 bp \\
\hline & $5^{\prime}$-ccctgcctgactcagaggt $-3^{\prime}$ & $85-103$ & 60 & \\
\hline
\end{tabular}

For simplicity, we will refer to Tgfbr $2^{f l f l} ; \alpha$-Cre mice as Tgfbr $2^{\Delta o c}$ mice; however, mice with two unrecombined $T g f b r 2^{f l f l}$ alleles are referred to as controls. In Tgfbr $2^{\Delta o c}$ mice, exon 2 of Tgfbr 2 was removed by Cre recombinase. To analyze if in mixed Tgfbr $2^{\Delta o c}$ mice recombination occurs throughout the entire retina, we used primer pairs that had been shown to amplify a PCR product when exon 2 is removed (Chytil et al., 2002). We detected the PCR product in genomic DNA from the central, intermediate, and peripheral sections of the retina (Fig. $1 A$ ). We next investigated the presence of T $\beta$ RII in the retina of P10 pups by immunohistochemistry. In control mice, distinct immunoreactivity for T $\beta$ RII was observed in the ganglion cell layer of both the peripheral and central inner retina, but the signal was barely detectable in the outer retina (Fig. $1 B$ ). In contrast, in the retinae of $T g f b r 2^{\Delta o c}$ littermates, T $\beta$ RII immunoreactivity was considerably weaker or absent, a finding that was equally observed both in the central retina near the optic nerve and in the peripheral retina near the ora serrata (OS) (Fig. 1C). We next performed Western blot analyses to detect T $\beta$ RII in protein extracts of the retinae from adult control and conditional T $\beta$ RII-deficient Tgfbr $2^{\Delta o c}$ littermates. For T $\beta$ RII, a distinct band was detected in the retinal proteins of control mice, which migrated at the expected molecular weight of $70 \mathrm{kDa}$ (Fig. 1D). By relative densitometry, the band was found to be significantly less intense in T $\beta$ RIIdeficient mice when compared with control littermates $(0.31 \pm 0.08$ vs $1 \pm 0.21, n \geq 4, p=0.02)$.

To investigate the activity of TGF- $\beta$ signaling in the retinae of control and Tgfbr $2^{\Delta o c}$ littermates, the retinal pSmad3 immunoreactivity was analyzed. In control mice, distinct immunostaining was detected that was confined to the nuclei in the inner nuclear layer (INL) and the ganglion cell layer with preference for the latter (Fig. 2A). The intensity of the staining did not differ between the central and the peripheral sections of the retina (Fig. $2 A, B)$. In contrast, pSmad3 immunoreactivity was considerably weaker or absent in the retinae of Tgfbr $2^{\Delta o c}$ littermates, a finding that was observed for both central and peripheral retinae (Fig. $2 A, B)$. No green immunofluorescence was observed when primary antibodies were omitted, verifying the specificity of secondary antibodies and successful destruction of eGFP activity (originating from the $\alpha$-Cre background) by fixation and paraffin embedding (Fig. 2C). Western blot analyses detected $\mathrm{pSmad} 3$ at the expected molecular weight of $54 \mathrm{kDa}$ in retinal proteins of adult control mice (Fig. 2D). By relative densitometry, the band was found to be significantly less intense in Tgfbr $2^{\Delta o c}$ mice compared with control littermates $(0.49 \pm 0.10$ vs $1 \pm 0.22, n=5, p=$ $0.05)$. Overall, the results strongly indicated a conditional deletion of T $\beta$ RII stretching from the central to the peripheral retina in $T g f b r 2^{\Delta o c}$ mice and a resulting significant attenuation of TGF- $\beta$ signaling in cells derived from the inner layer of the optic cup.

\section{Conditional deletion of T $\beta$ RII increases retinal apoptosis in mouse pups}

To study if the conditional inactivation of T $\beta$ RII had an influence on the rate of apoptotic cell death in the postnatal retina, TUNEL was performed. At P4, P7, and P10, TUNEL-positive nuclei were observed, which were homogenously distributed throughout both central and peripheral regions of the retina (Fig. $3 A$ ). TUNEL-positive cells primarily localized to the inner retina and appeared to be more numerous in the Tgfbr $2^{\Delta o c}$ than in the control mice (Fig. 3A). The quantitative analysis confirmed our qualitative assessment and showed that in $T g f b r 2^{\Delta o c}$ eyes the number of TUNEL-positive cells was significantly higher ( $p=0.048$ at P4, $p=0.0089$ at $\mathrm{P} 7$, and $p=0.0086$ at $\mathrm{P} 10 ; n=6$ each) than in the controls (Fig. $3 B$ ). We used an additional independent and specific assay to quantify apoptosis and determined the relative amounts of cytoplasmic histone-associated DNA fragments (mononucleosomes and oligonucleosomes) by ELISA. A significantly higher level of cytoplasmic nucleosomes was observed in the retinae of P10 Tgfbr $2^{\Delta o c}$ animals compared with the controls $(1.49 \pm 0.18$ vs $1 \pm 0.08, n \geq 13, p=0.03)$. We concluded that the lack of T $\beta$ RII enhances programmed cell death in the retinae of P4-P10 Tgfbr $2^{\Delta o c}$ mice.

\section{Enhanced apoptosis during retinal development causes structural and functional changes in the retina of adult Tgfbr $2^{\Delta o c}$ mice}

We assumed that an increase in programmed cell death in the retina of mouse pups will lead to a lower number of retinal neurons in adult mice. To assess this hypothesis, we first analyzed the thickness of both the INL and the outer nuclear layer (ONL) on mid-horizontal sections through Tgfbr $2^{\Delta o c}$ and control eyes (Fig. $4 A, B)$. Throughout the circumference of the retina, the thickness of the INL was consistently and significantly $(p=0.001$ to $p=$ $0.05, n=5$ ) reduced in Tgfbr $2^{\Delta o c}$ eyes compared with the control eyes (Fig. 4A). A significant reduction ( $p=0.005$ to $p=0.047$, $n=5)$ in the thickness of the nasal ONL was also observed in $T g f b r 2^{\Delta o c}$ eyes; however, the thickness of the temporal ONL was largely comparable to the thickness observed in the control eyes (Fig. 4B). To analyze the number of retinal ganglion cells, optic nerve axons were used as a measure and were counted in the optic nerves of 8-week-old animals (Fig. 4C). Quantitative analysis of the number of cross-sectioned optic nerve axons showed that 43,938 \pm 1356 (mean \pm SEM) axons were present in the control animals; 

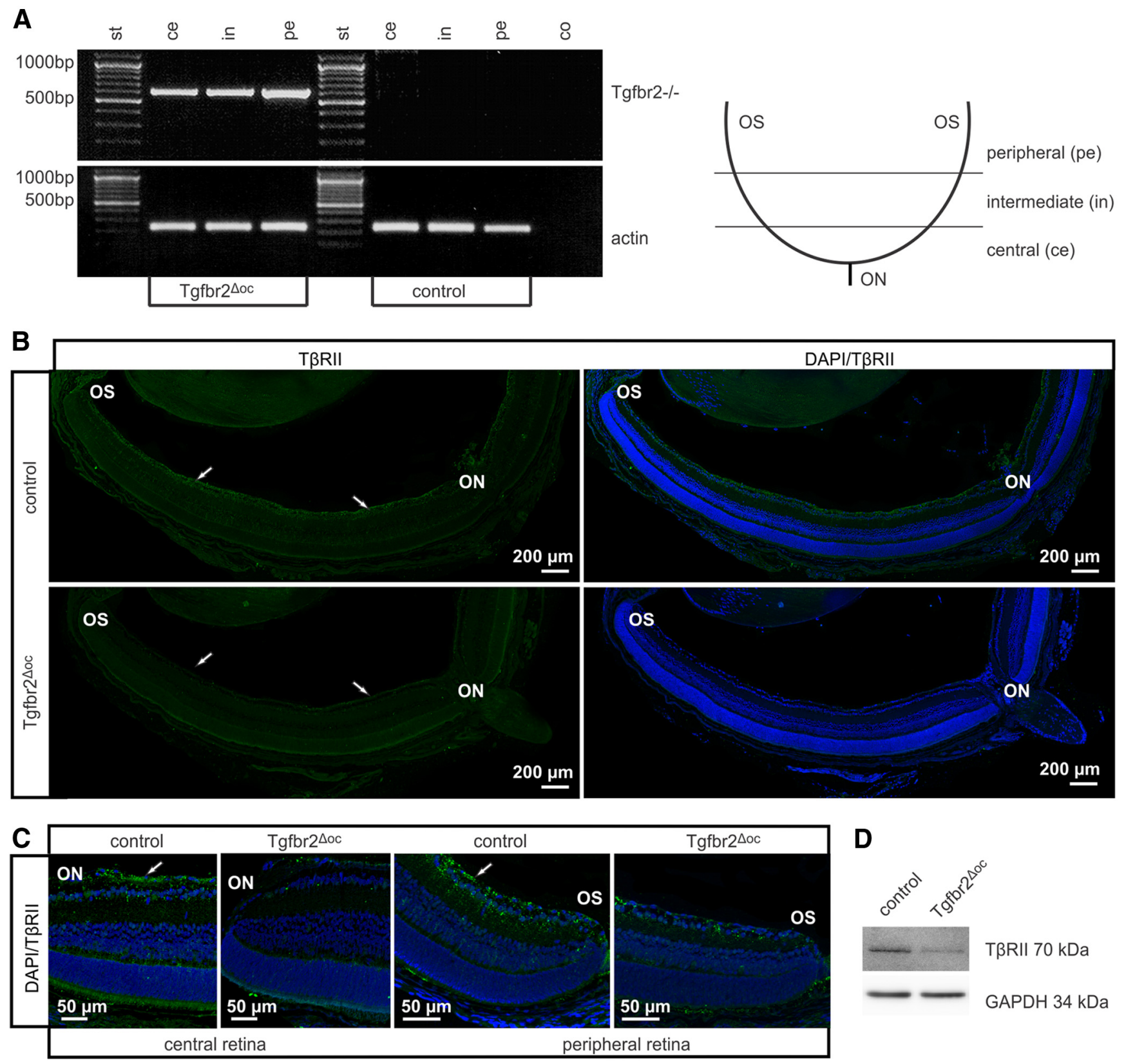

D

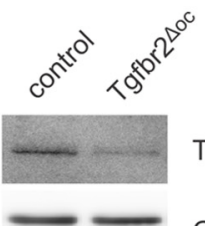

TßRII $70 \mathrm{kDa}$

GAPDH 34 kDa

Figure 1. The characterization of the T $\beta R$ III deletion in $T g f b r 2^{\Delta o c}$ neural retinae. $A$, Tgfbr2 deletion PCR with retinal genomic DNA of an adult Tgfbr $2^{\Delta o c}$ mouse and its control littermate. Due to their different product sizes (product size control: 3974 bp, product size after Tgfbr2 deletion: $636 \mathrm{bp}$ ) and the PCR elongation time of 1 min, the Tgfbr 2 deletion PCR product was only amplified after Cre-mediated recombination. In Tgfbr ${ }^{\Delta o c}$ mice recombination occurred throughout the entire retina (central, intermediate, and peripheral regions). $\boldsymbol{B}$, Immunoreactivity for T $\beta R I I$ (green) in the retina of a $T g f b r 2^{\Delta o c}$ mouse and its control littermate at P10. Distinct immunoreactivity for T $\beta R l l$ was detectable in the ganglion cell layer (arrows) of both peripheral and central inner retina in the control animal but was absent in the central and peripheral retina of $T g f b r 2^{\Delta o c}$ littermates. Nuclei are stained with DAPI (blue). C, Detailed view of the central and peripheral retina of a $T g f b r 2^{\Delta o c}$ and its control littermate at P10 immunostained for T $\beta$ RII (green). In the retina of the $\mathrm{Tgfbr}{ }^{\Delta o c}$ animal, immunoreactivity for T $\beta$ RII was considerably weaker or absent when compared with the control littermate (arrows), a finding equally observed both in the central retina and in the peripheral retina. $\boldsymbol{D}$, Western blot analysis for T $\beta$ RII in retinal proteins from adult animals. GAPDH was used as the loading control. Ce, central; in, intermediate; pe, peripheral; co, negative control, st, standard; $0 \mathrm{~N}$, optic nerve; $0 \mathrm{~S}$, ora serrata.

however, Tgfbr $2^{\Delta o c}$ eyes only contained $26,996 \pm 2537$ (mean \pm SEM) axons, which was a statistically significant difference $(p=$ $0.0019, n=4)$. To analyze whether the loss of optic nerve axons in $\mathrm{Tg} f b r 2^{\Delta o c}$ animals correlated with a loss of retinal ganglion cell perikarya, mid-horizontal sections through $\mathrm{Tg} f b r 2^{\Delta o c}$ and control eyes were analyzed (Fig. 4C). In correlation with the amount of axons in the optic nerves, significantly more ( $343.4 \pm 5.92$ vs $276.4 \pm 15.33$, $p=0.0065, n=5$ ) neuronal perikarya were observed in the ganglion cell layer of control eyes compared with $T g f b r 2^{\Delta o c}$ eyes.
To obtain information regarding the nature of the neurons that were reduced in number in the INL causing a reduction in its thickness, we performed immunohistochemistry to detect calbindin, which is expressed in the mouse retina in ganglion cells, horizontal cells, and several amacrine cells, or calretinin, a marker for ganglion cells and amacrine cells (Haverkamp and Wässle, 2000). At P10, calbindin-positive perikarya were observed in the ganglion cell layer and at the inner and outer aspect of the INL (Fig. 5A). Staining for calretinin was observed in the 

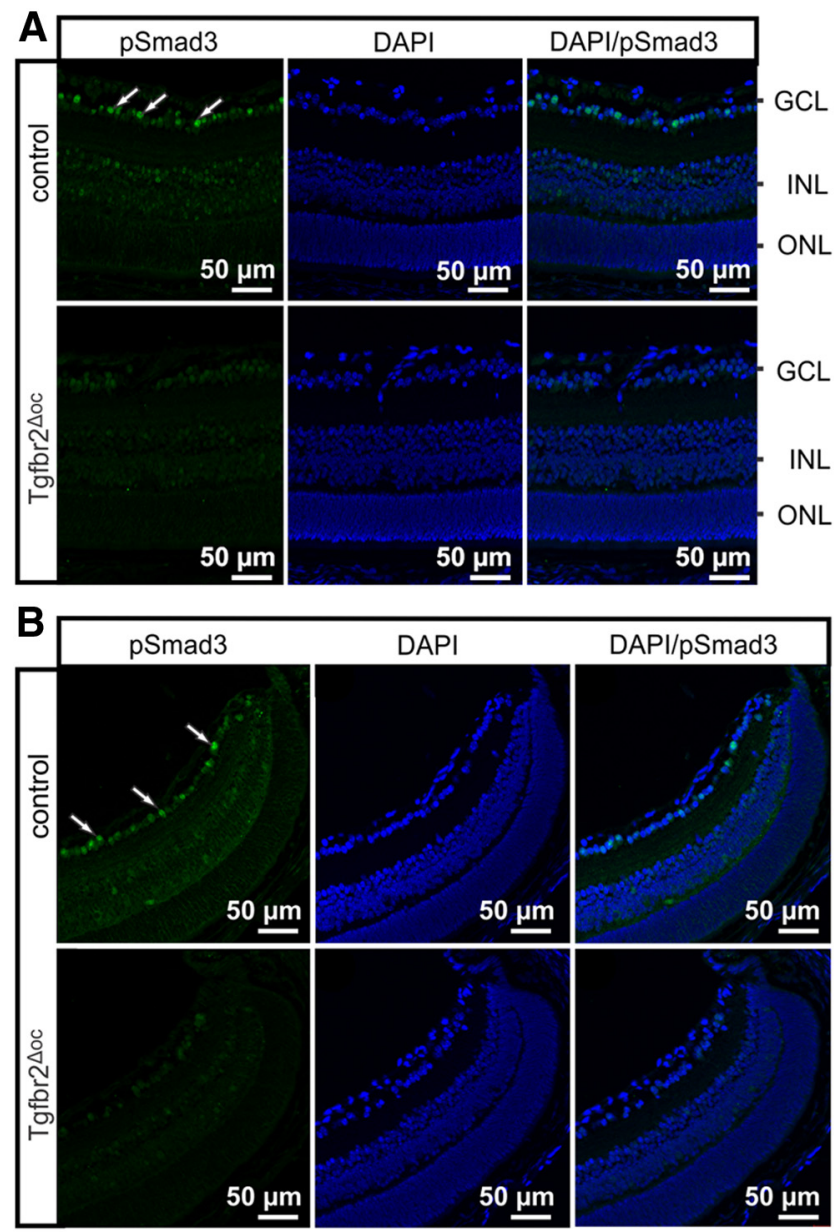

$\mathrm{DAPl} / \mathrm{pSmad} 3$
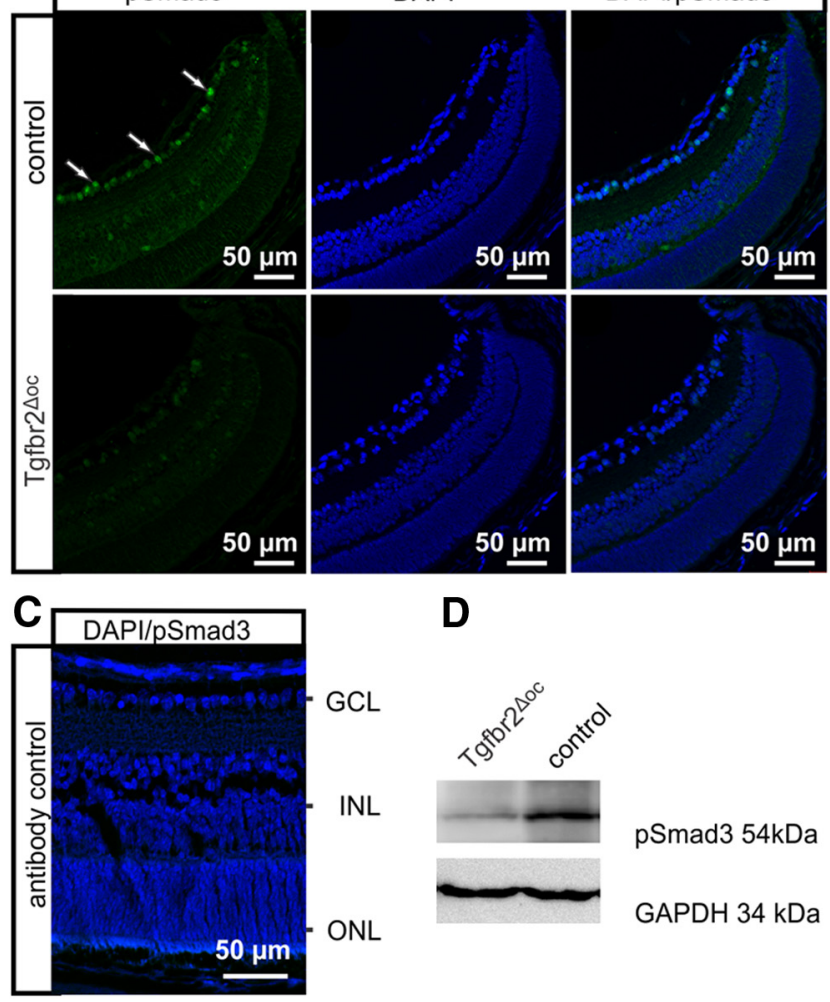

D

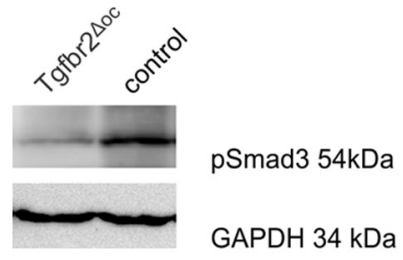

Figure 2. Smad3 activity in $T g f b r 2^{\Delta o c}$ neural retinae. $\boldsymbol{A}, \boldsymbol{B}$, Immunoreactivity for pSmad3 (green) in the central $(\boldsymbol{A})$ or peripheral ( $\boldsymbol{B})$ retina of a $\mathrm{Tgfbr} 2^{\Delta o c}$ mouse and its control littermate at P10. The control animal showed distinct immunoreactivity for pSmad3 in the nuclei of the inner retina with preference to the ganglion cell layer (GCL). In contrast, in the $T g f b r 2^{\Delta o c}$ littermate, immunoreactivity for pSmad3 was considerably weaker or absent. Staining intensity did not differ between the central and peripheral parts of the retina in the $T g f b r 2^{\Delta o c}$ mouse nor in the control mouse. Nuclei were stained with DAPI (blue). C, Antibody control sections indicated the specificity of the secondary antibody and the successful destruction of eGFP activity by fixation and paraffin embedding (originating from the $\alpha$-(re background). D, Western blot analyses for pSmad3 in retinal proteins of control mice and T $\beta$ RII-deficient mice. GAPDH was used as the loading control.

perikarya of the ganglion cell layer and at the inner aspect of the INL (Fig. 5B). Comparable results were observed at P7, while no immunoreactivity for calretinin or calbindin was observed at P4, which indicates their expression upon differentiation. When we quantified the number of perikarya in the ganglion cell layer that were labeled for calbindin or calretinin, we observed a significant reduction in their number in $\mathrm{P} 10 \mathrm{Tgfbr} 2^{\Delta o c}$ eyes $(p=0.001$ for
A

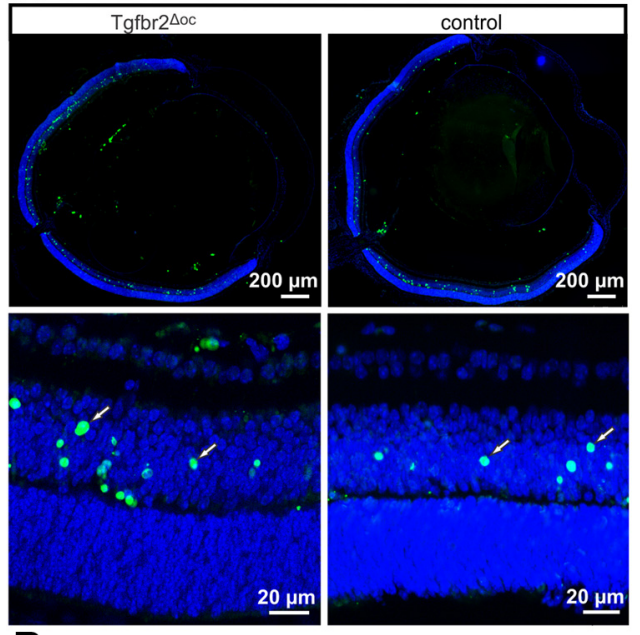

B

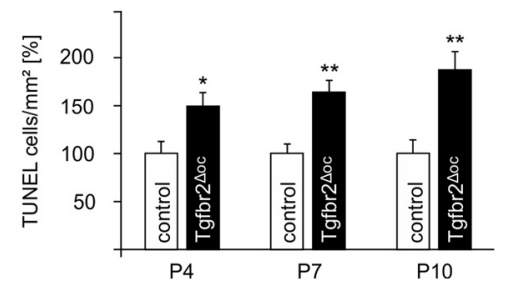

Figure 3. Increased programmed cell death during synaptogenesis of $\operatorname{Tgfbr}{ }^{\Delta \circ \mathrm{C}}$ retinae. $\boldsymbol{A}$, TUNEL-labeling (green) of a P7 retina in a Tgfbr ${ }^{\Delta o c}$ mouse and its control littermate. The bottom showed higher magnification of the central retina. TUNEL-positive nuclei (arrows) localized to the inner retina and appeared to be more numerous in the $\operatorname{Tgfbr}^{\Delta o c}$ mouse. Nuclear DNA was stained with DAPI (blue). B, Quantification of TUNEL-labeled cells. The total number of labeled cells was counted at P4, P7, P10, and normalized to the area of the retina (means \pm SEM, ${ }^{*} p=0.048$ at P4, ${ }^{*} p=0.0089$ at P7 and ${ }^{* *} p=0.0086$ at P10, $n=6$ each).

calbindin and $p=0.01$ for calretinin, $n=5$ ), a finding that markedly correlated with the significant reduction of perikarya in the ganglion cell layer of adult eyes (Fig. 5C). In addition, we observed a significant reduction of calbindin-labeled $(p=$ $0.00009, n=5)$ or calretinin-labeled ( $p=0.004, n=5)$ perikarya at the inner aspect of the INL in Tgfbr2 ${ }^{\Delta o c}$ eyes indicating a reduction in the number of amacrine cells. Similarly, we observed a reduction of calbindin-positive perikarya $(p=0.013, n=5)$ at the outer aspect of the INL corresponding to a reduction in the number of horizontal cells. We next performed double-labeling experiments with TUNEL staining to observe that no colocalization with calbindin or calretinin immunoreactivity occurred at P10 or P7. This finding indicated that the differences in apoptosis in the ganglion cell layer and INL between control and Tgfbr $2^{\Delta o c}$ eyes were caused by differences in the activity of TGF- $\beta$ signaling on progenitor cells compared with differentiated neurons. TUNEL-positive nuclei in the INL at P10 and P7 stained for Pax6, which indicates that they originated in the optic cup (Fig. 5D). We concluded that the TUNEL/Pax6-positive cells at P7 and P10 were largely destined to become bipolar cells, which have their peak in programmed cell death at this period (Young, 1984). Overall, our findings showed that changes in the number of all three major neuronal cell types (bipolar, amacrine, and horizontal cells) contributed to the decrease in the thickness of the INL in adult $T g f b r 2^{\Delta o c}$ eyes.

We next analyzed if the observed structural changes in the retina of Tgfbr $2^{\Delta o c}$ mice caused functional changes. To this end, we performed ERG analyses to observe that for dark-adapted, standard single-flash ERGs, the response amplitudes and implicit 

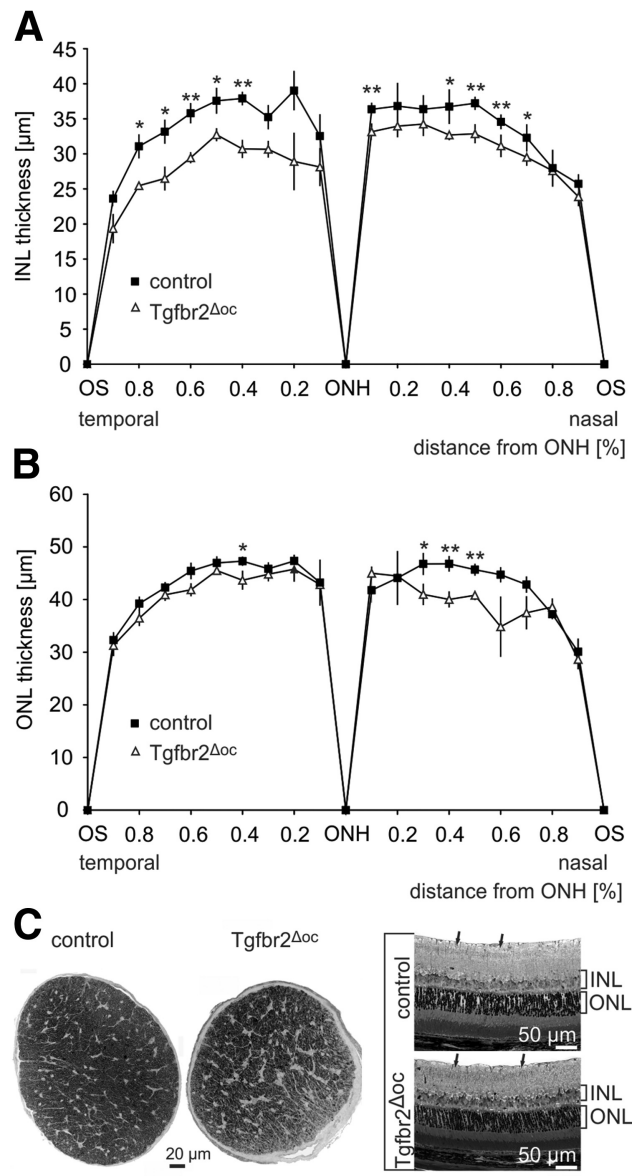

Figure 4. The loss of retinal ganglion cells and neurons in the INL of adult $T g f b r 2^{\Delta o c}$ mice. $A$, $\boldsymbol{B}$, The thickness of the INL $(\boldsymbol{A})$ and ONL $(\boldsymbol{B})$ measured on mid-horizontal semithin sections through eyes of 8-week-old $\mathrm{Tgfbr}^{\mathrm{Aoc}}$ mice and control littermates. The distance between the $0 S$ and the $0 \mathrm{NH}$ was divided into tenths and measured between each tenth. Mean $\pm \mathrm{SEM}, n=$ 5 each, ${ }^{* *} p<0.01,{ }^{*} p<0.05$. C, Cross sections through optic nerves (PPD stain) and midhorizontal sections through the central retina (Richardson's stain) of an 8-week-old control mouse and its $\mathrm{Tgfbr}^{\Delta{ }^{\Delta o c}}$ littermate. Semithin sections, $1 \mu \mathrm{m}$ thick. Cells in the retinal ganglion cell layer were labeled with arrows.

times of the a- and b-wave were similar for both $T g f b r 2^{\Delta o c}$ and control mice (Fig. 6A), which indicated that similar photoreceptor and bipolar cell function occurred as determined by the a-wave and b-wave parameters, respectively. Similarly, the magnitude and phase of the response waveforms to scotopic flicker of various frequencies (in the main reflecting bipolar cell function with very little contributions of photoreceptor or inner retinal neurons) of $T g f b r 2^{\Delta o c}$ mice did not differ from controls. Lightadapted responses to flickering stimuli also showed no difference. Additionally, amplitudes and implicit times of the oscillatory potentials generated by horizontal and other early inner retinal cell interactions did not differ between $T g f b r 2^{\Delta o c}$ and control mice.

In contrast, distinct differences were observed with regard to cone bipolar cell dominated responses to single flashes of higher intensities recorded under light-adapted conditions, which showed significantly prolonged implicit times $(p=0.017, p=$ 0.0199 , and $p=0.0286$ for the three flash intensities, respectively) and lower b-wave amplitudes $(p=0.123, p=0.039$, and $p=$ 0.034 ) in $T g f b r 2^{\Delta o c}$ animals when compared with controls (Fig. $6 B$ ). Moreover, dark-adapted STRs elicited by very weak white flashes showed lower b-wave and STR amplitudes for Tgfbr $2^{\Delta o c}$ mice compared with controls and similar implicit times (Fig. 6C).
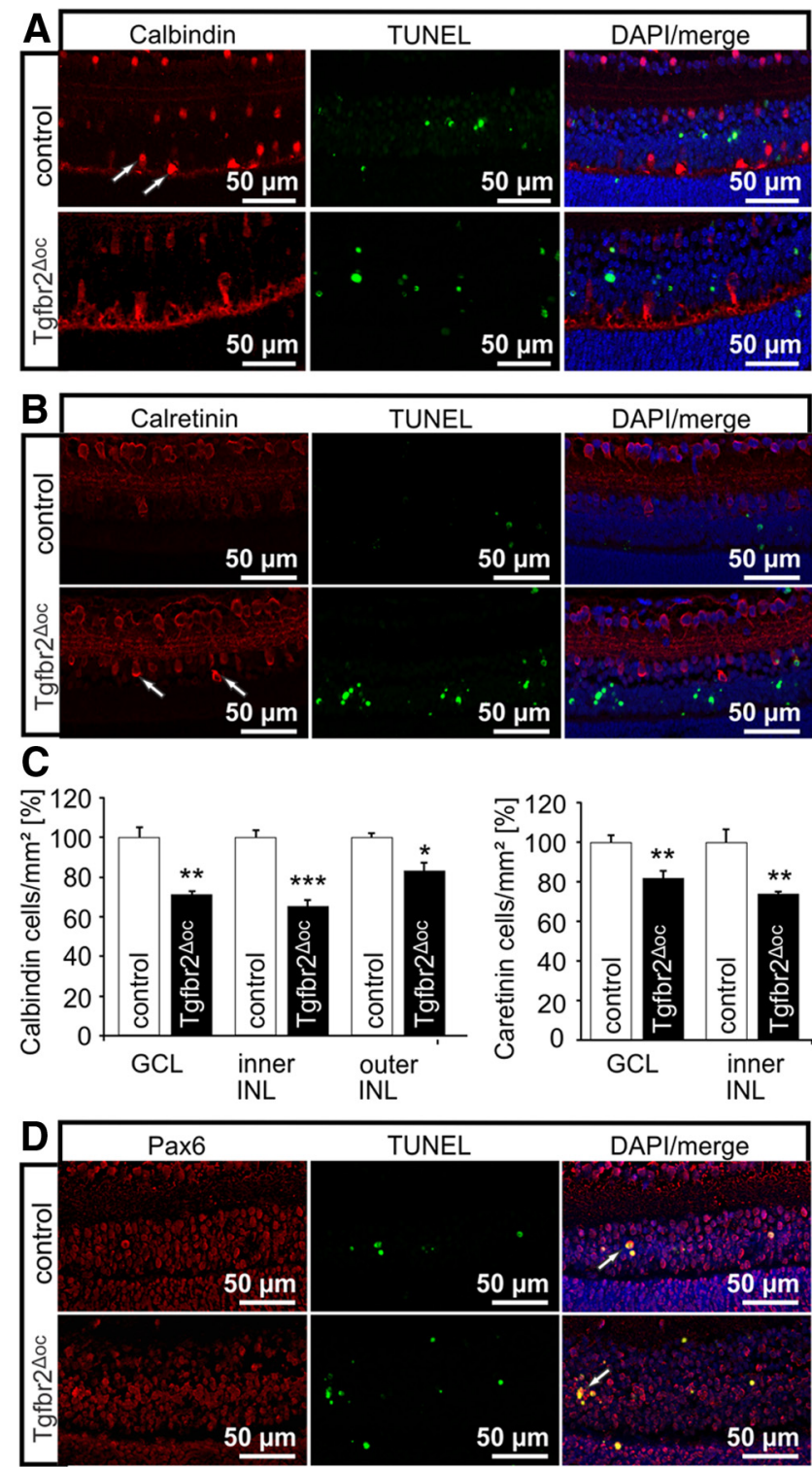

Figure 5. Characterization of the apoptotic cells in $T g f b r 2^{\Delta o c}$ mice. $A$, Immunofluorescence double staining for TUNEL-labeling (green) and calbindin (red) of a P10 retina in a $T g f b r 2^{\Delta o c}$ mouse and its control littermate. Calbindin-labeled retinal ganglion cells, horizontal cells (arrows), and several amacrine cells. Nuclei were stained with DAPI (blue), $\boldsymbol{B}$, Immunofluorescence double staining for TUNEL-labeling (green) and calretinin (red) of a P10 retina in a Tgfbr ${ }^{\Delta o c}$ mouse and its control littermate. Calretinin-labeled retinal ganglion cells, and amacrine cells (arrows). Nuclei were stained with DAPI (blue). C, Quantification of calbindin- and calretininpositive cells in the ganglion cell layer $(\mathrm{GCL})$ and the inner or outer aspects of the INL of P10 retinae in $T g f b r 2^{\Delta o c}$ mice and control littermates. The number of positive cells was normalized to the area of GCL or INL. D, Immunofluorescence double staining for TUNEL-labeling (green) and Pax6 (red) of a P10 retina in a Tgfbr $2^{\Delta o c}$ mouse and its control littermate. Nuclei were stained with DAPI (blue).

These two components (STR and b-wave) have been shown to have proximal retinal origin (Saszik et al., 2002). Overall, ERG analysis indicated normal rod and cone photoreceptor function, but was consistent with a postreceptoral degeneration dominated by the loss of proximal retinal neurons.

\section{TGF- $\beta 2$ attenuates retinal ganglion cell death in} newborn mice

To assess the hypothesis that a lack of TGF-signaling enhances apoptosis of retinal neurons in mouse pups, we next analyzed if 
A

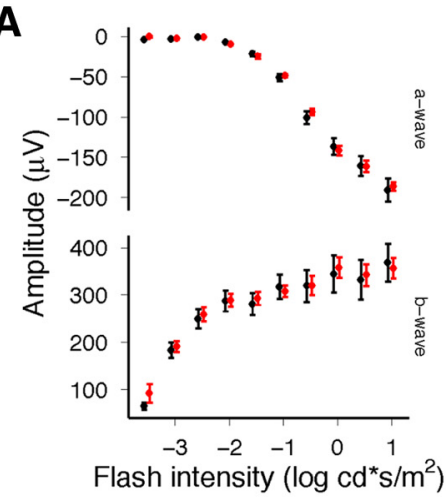

B

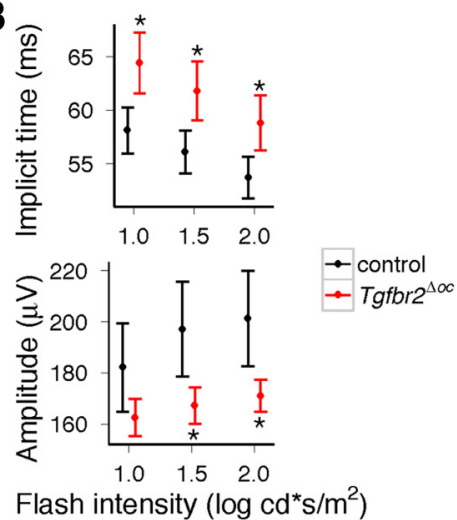

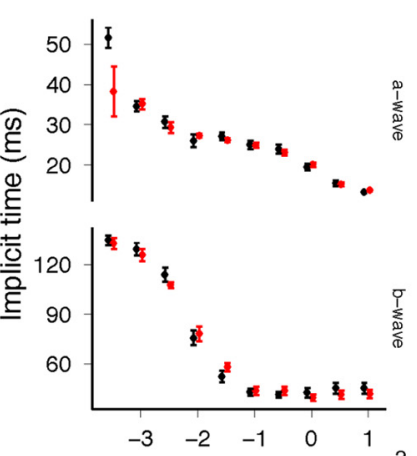

Flash intensity $\left(\log \mathrm{cd}^{*} \mathrm{~s} / \mathrm{m}^{2}\right)$

C

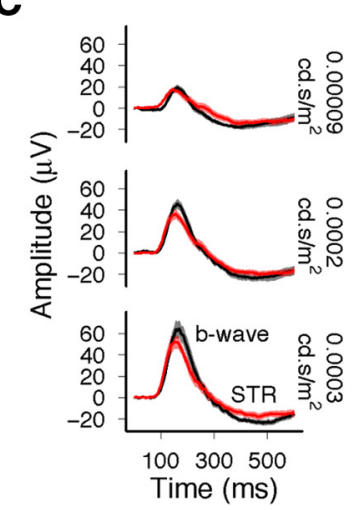

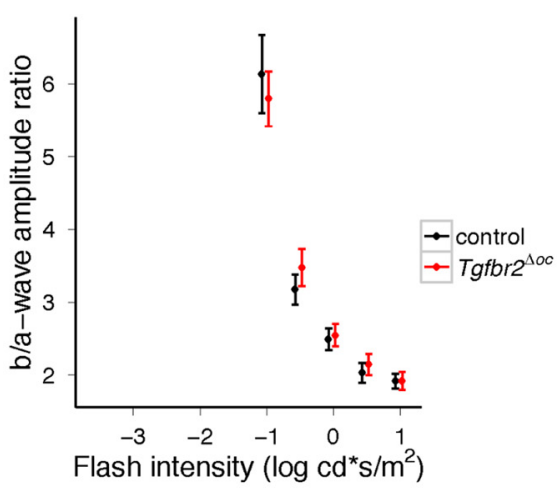

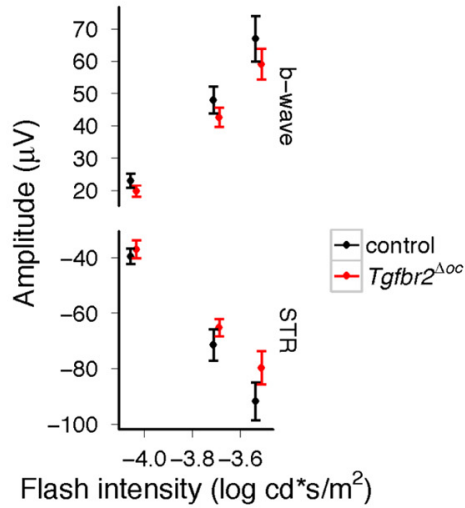

Figure 6. Functional deficits in the retinae of adult $T g f b r 2^{\Delta o c}$ mice. The average ERG waveforms with SD to single flashes of increasing intensity showed similar amplitudes and implicit times of its trough (a-wave) and peak (b-wave) under dark-adapted condition ( $\boldsymbol{A}$ ); however, the amplitudes of the responses to single flashes recorded under light-adapted conditions were reduced, and implicit times were prolonged $\left(\boldsymbol{B},{ }^{*} p<0.05\right)$. The STRs elicited by very brief flashes of white light recorded under dark-adapted condition showed waveforms with a slight reduction of its peak amplitude (b-wave) and an elevation of the following trough (STR) (C).

increasing amounts of TGF- $\beta 2$ are capable of attenuating cell death of retinal neurons at this age. To this end, we established primary retinal cell cultures using the eyes of newborn mice. Retinal ganglion cells were labeled with TUJ1 (neuronal $\beta$ III tubulin; Fig. 7) and quantitatively evaluated. After $24 \mathrm{~h}$ in culture, the number of TUJ1-positive cells decreased by $>50 \%$ (Fig. 7). In contrast, when TGF- $\beta 2$ was added to culture wells at a concentration of $10 \mathrm{ng} / \mathrm{ml}$, significantly more retinal ganglion cells survived for $24 \mathrm{~h}$. The protective effect of TGF- $\beta 2$ was blocked in a dose-dependent manner when SIS3, an inhibitor of Smad3 phosphorylation, was simultaneously added (Fig. 7).

\section{The reduced number of retinal neurons in $T g f b r 2^{\Delta o c}$ mice is not due to lack of proliferation}

An increase in apoptosis of progenitor cells during embryonic development of the retina may also contribute to the reduced number of retinal neurons in the inner retina, which we observed in the eyes of adult $\mathrm{Tg} f b r 2^{\Delta o c}$-deficient mice. To further study this possibility, we performed TUNEL-labeling in embryos at E12.5, E14.5, and E16.5 of age. TUNEL-positive cells were readily observed in the retina, the vitreous, and the lens epithelium (Fig. $8 A$ ). When TUNEL-positive cells were quantitatively evaluated, a significantly $(p=0.049$ at E12.5, $p=0.042$ at E14.5, and $p=$ 0.0030 at E16.5; $n=9-13$ ) higher number of TUNEL-positive cells was observed in $T g f b r 2^{\Delta o c}$ eyes at all three embryonic stages, a finding quite comparable to the number in the mouse pups (Fig. $8 B$ ). Next we clarified whether a change in progenitor cell proliferation may account for the difference in the number of retinal ganglion cells in adult mice. To this end, we analyzed
BrdU-labeled retinae of embryonic mice at E16.5 when the proliferation of retinal ganglion cell progenitors is at its peak (Sidman, 1961). Multiple cells with BrdU-positive nuclei were observed in the retinae of both control and Tgfbr $2^{\Delta o c}$ mice (Fig. $8 C$ ). The quantitative analysis of the number of BrdU-positive cells did not show a significant difference between $\mathrm{Tg} f b r 2^{\Delta o c}$ and control eyes $\left(2394.07 \pm 214.056\right.$ positive cells per $\mathrm{mm}^{2}$ vs $2496.95 \pm 184.39, n \geq 8)$.

\section{Smad7 deficiency in the developing retina enhances TGF- $\beta$ signaling and reduces apoptosis}

Our results indicated that lack of TGF- $\beta$ signaling in retinal neurons increased the probability of their elimination by programmed cell death during retinal development. Therefore, we hypothesized that an increase in retinal TGF- $\beta$ signaling during development should have the reverse effect, quite comparable to our findings in cultured retinal neurons upon treatment with TGF- $\beta 2$. To test this hypothesis, we generated $S m a d 7^{f l / f l} ; \alpha$-Cre mice with a conditional inactivation of Smad7 in the cells of the neural retina that are derived from the optic cup. For simplicity, we will refer to $S m a d 7^{f l f l} ; \alpha$-Cre mice as $S m a d 7^{\Delta o c}$ mice, while mice with two unrecombined $S m a d 7^{f l f l}$ alleles are referred to as the controls. By real-time RT-PCR, Smad7 mRNA was found to be significantly ( $p=0.006$ ) reduced in the RNA isolated from the retinae of P7 Smad $7^{\Delta o c}$ animals (Fig. 9A) compared with the control littermates. The reduction of Smad7 mRNA correlated with a considerable reduction of Smad7 as observed in Western blot analysis of retinal proteins (Fig. 9B). In contrast, the mRNA expression of genes that are characteristically induced by TGF- $\beta$ 

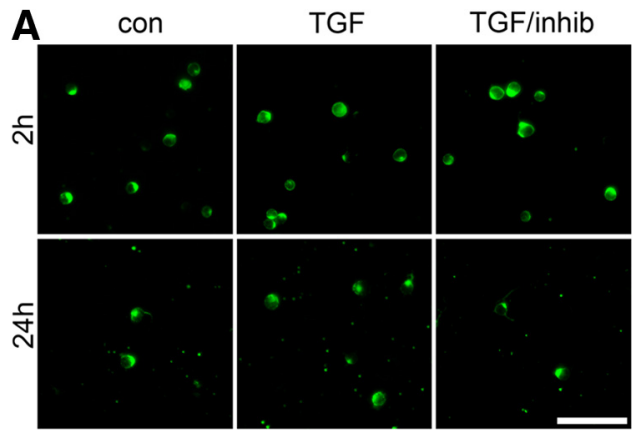

B

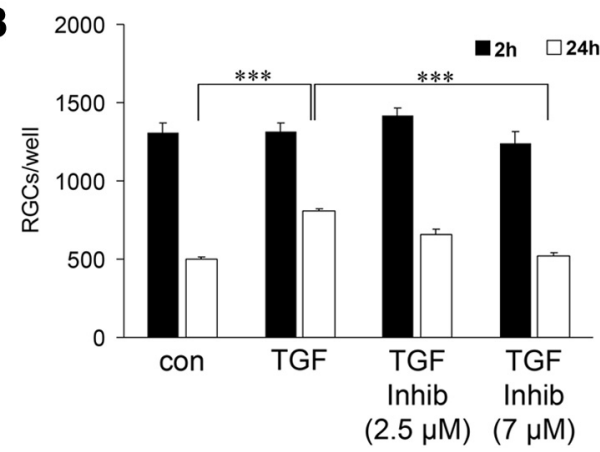

Figure 7. TGF- $\beta 2$ increased the survival of the retinal ganglion cells (RGCS) in dissociated retinal cell cultures. $\boldsymbol{A}, \mathrm{RGCs}$ in dissociated retinal cultures derived from postnatal (P0) mice labeled with antibodies against $\beta$ III-tubulin after $2 \mathrm{~h}$ or $24 \mathrm{~h}$ in culture. Cells were treated with TGF- $\beta 2$ (TGF), TGF- $\beta 2$ in combination with SIS3, an inhibitor of Smad3 phosphorylation (TGF/ inhib), or vehicle (con). Scale bar, $50 \mu \mathrm{m}$. $\boldsymbol{B}$, The number of RGCs/well after $2 \mathrm{~h}$ (black bars) or $24 \mathrm{~h}$ (white bars) and treated as described in $\boldsymbol{A}\left({ }^{* * *} p=8.6^{*} 10^{-6}\right.$ con vs TGF; ${ }^{* *} p=0.00097$ TGF vs TGF + Inhib.).

signaling such as Ctgf and Fn1 (encoding for connective tissue growth factor and fibronectin, respectively) was significantly higher $(p=0.014$ for Ctgf, $p=0.048$ for Fn1) in retinal RNA from Smad7 ${ }^{\Delta o c}$ animals than in control littermates (Fig. 9A). Moreover, pSmad3 levels were markedly higher in retinal proteins from Smad $7^{\Delta o c}$ animals compared with the control littermates (Fig. 9C). By densitometry, we detected a threefold increase in the amount of pSmad3 in the retinae of Smad $7^{\Delta o c}$ mice ( $3.069 \pm 0.90$ vs $1.0 \pm 0.21, p=0.050, n=5)$ compared with the controls. Immunohistochemistry also indicated a considerable increase in $\mathrm{pSmad} 3$ levels. Accordingly, pSmad3 immunoreactivity in $S m a d 7^{\Delta o c}$ mice was more intense in the nuclei of the ganglion cell layer when compared with the controls. Moreover, immunostaining for $\mathrm{pSmad} 3$ was now observed throughout the entire inner plexiform and nuclear layers (Fig. 9D). Overall, the data strongly indicated higher activity of TGF- $\beta$ signaling in the retinae of Smad $7^{\Delta o c}$ mice compared with the control littermates. Finally, we investigated programmed cell death of the retinae by TUNEL-labeling at E16.5, P7, and P10. At all three stages, the number of TUNEL-positive cells was significantly higher (E 16.5, $p=0.0035, n=8 ; \mathrm{P} 7, p=0.028, n \geq 9$; and P10, $p=0.020, n=6$ ) in the controls than in the Smad $7^{\Delta o c}$ mice (Fig. $9 E)$. We further analyzed whether the changes in developmental apoptosis of retinal neurons caused alterations in the adult retinal phenotype. As a measure of the number of retinal ganglion cells, we counted the total number of optic nerve axons in cross sections (Fig. 9F). Both at 2 months $(47,777.50 \pm 892.20$ vs 40,3345.88 \pm 2284.67, $p=0.020, n \geq 6)$ and 6 months $(49,866.71 \pm 1897.30$ vs $41,902.71 \pm 1169.58, p=0.0038, n=7)$ of age, optic nerves of $S m a d 7^{\Delta o c}$ mice contained a significantly higher number of axons than compared with the controls. In

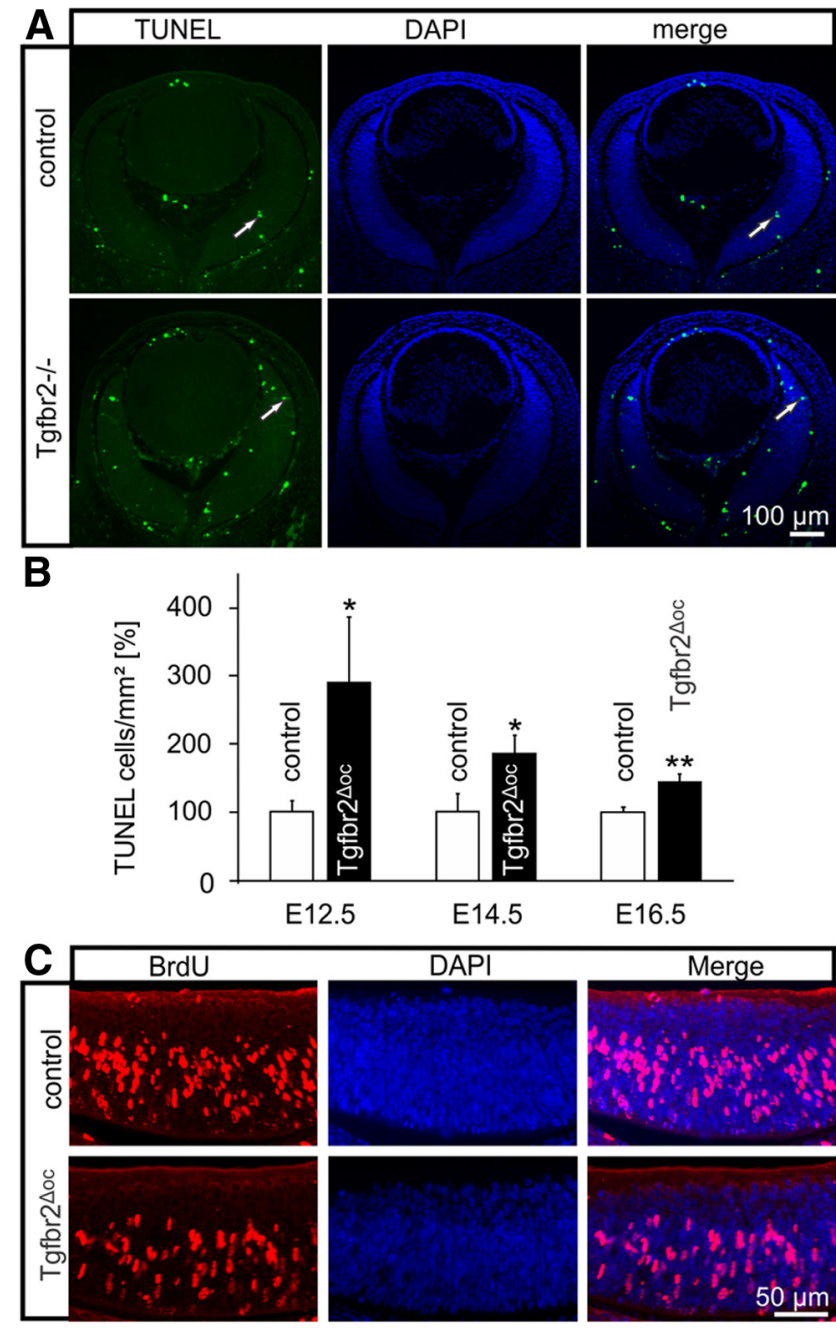

Figure 8. The proliferation and apoptosis of progenitor cells in Tgfbr2 ${ }^{\Delta o c}$ embryos. $\boldsymbol{A}_{\text {, }}$ TUNEL-labeling (green, arrows) of the eye of an E14.5 Tgfbr ${ }^{\Delta o c}$ embryo and its control littermate. Nuclear DNA was stained with DAPI (blue). $\boldsymbol{B}$, The quantification of TUNEL-labeled cells. The total number of labeled cells was counted at E12.5, E14.5, and E16.5 and was normalized to the area of the retina (mean $\pm \mathrm{SEM}, n \geq 9,{ }^{*} p=0.0494$ at E12.5, ${ }^{*} p=0.0420$ at E14.5, ${ }^{* *} p=0.0030$ at E16.5). C, BrdU labeling (red) of E16.5 retinae in a Tgfbr ${ }^{\Delta 0 c}$ embryo and its control littermate.

summary, our findings in $S m a d 7^{\Delta o c}$ mice provide further support that TGF- $\beta$ signaling in the developing retina attenuates programmed cell death.

\section{The expression of NGF in the retina of mouse pups is} regulated by TGF- $\beta$-signaling

To analyze whether the protective effect of TGF- $\beta$ signaling against developmental programmed cell death is mediated by an increased expression of a specific neuroprotective factor in the retina, we analyzed RNA isolated from the retinae of P10 $T g f b r 2^{\Delta o c}$ and $S m a d 7^{\Delta o c}$ mouse pups by real-time RT-PCR. We did not find significant changes in the expression of brainderived neurotrophic factor $(B d n f)$, neurotrophin-3 (Ntf3), ciliary neurotrophic factor ( Cntf), fibroblast growth factor-2 $(F g f 2)$, glial cell-derived neurotrophic factor $(G d n f)$, endothelin-2 $(E d n 2)$, or vascular endothelial growth factor (Vegf). The mRNA of leukemia inhibitory factor was barely detectable, both in $T g f b r 2^{\Delta o c}$ mice and their control littermates. In contrast, RNA from the retinae of $T g f b r 2^{\Delta o c}$ pups contained a significantly lower $(p=0.021)$ amount of mRNA for $N g f$ (Fig. 10A). Quite intrigu- 


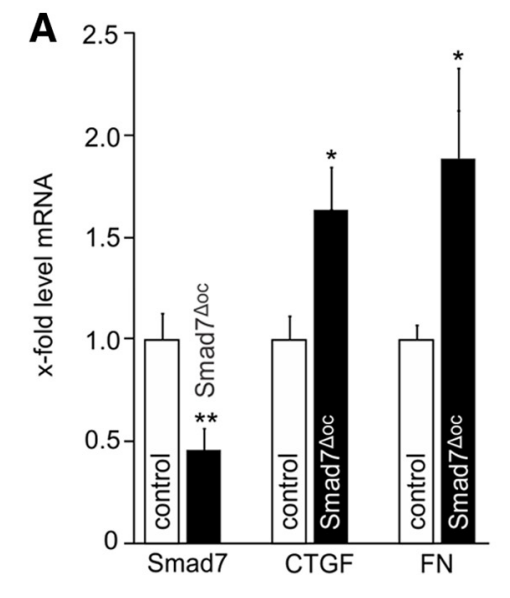

B

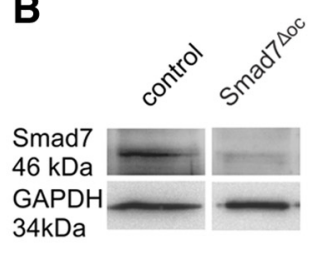

C
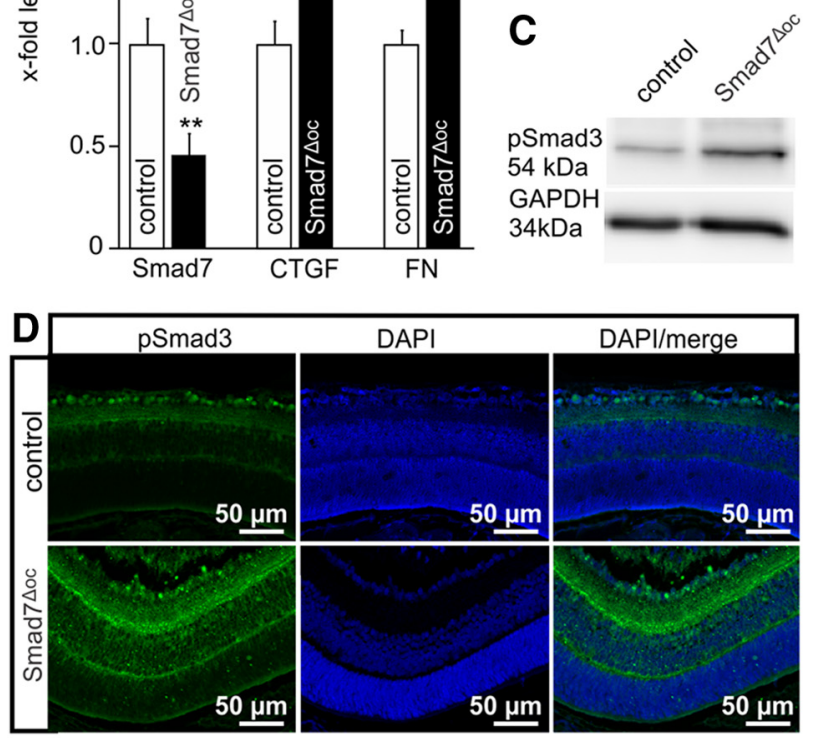

$\mathrm{DAPI} /$ merge

E
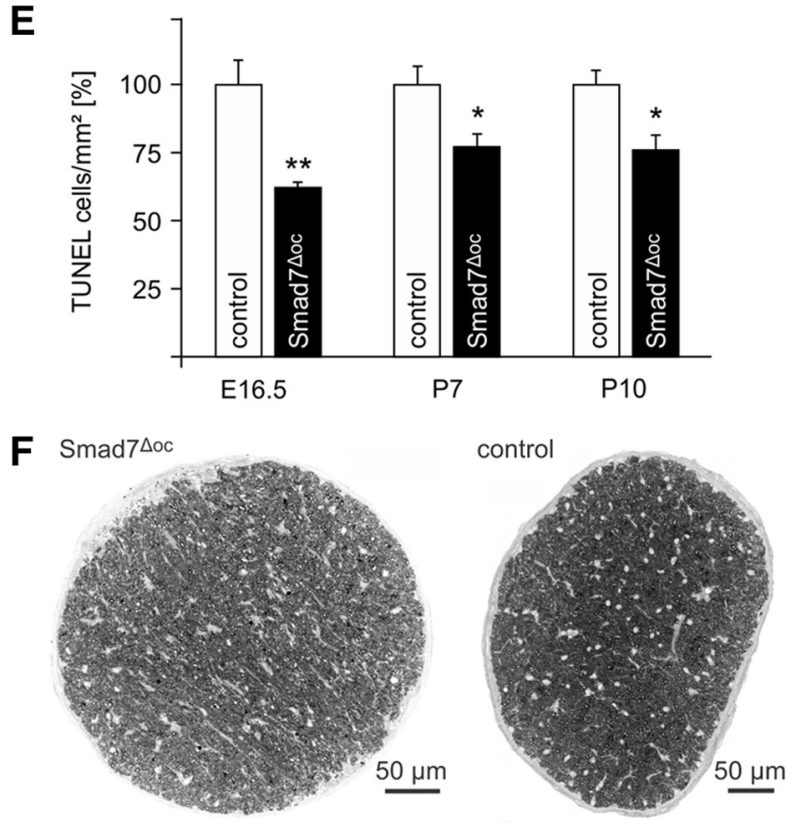

Figure 9. Programmed cell death decreased in the retinae of $S m a d 7^{\Delta o c}$ mice. A, Quantitative real-time RT-PCR of $S \mathrm{mad} 7, \mathrm{Ctgf}$, and $F n 1 \mathrm{mRNA}$ in conditional $S \mathrm{mad} \mathrm{7}^{\Delta{ }^{\circ c}}$ mice and control littermates (mean \pm SEM $, n \geq 5,{ }^{* *} p=0.0061$ Smad7,${ }^{*} p=0.0144$ (tgf ${ }^{*} p=0.0484$ Fn 1 ). Expression was normalized to Gapdh. $\boldsymbol{B}$, Western blot analysis for Smad7 in the retinal proteins of $S \mathrm{mad} 7^{\Delta o c}$ and control retinae. GAPDH was used as the loading control. $C$, Western blot analysis of pSmad3 in the retinae of $S \mathrm{mad} 7^{\mathrm{\Delta oc}}$ and control retinae. GAPDH was used as loading control. $\boldsymbol{D}$, Immunoreactivity of pSmad3 (green) in the central retina of a Smad $7^{\Delta o c}$ mouse and its control littermate at P10. The control animal showed distinct immunoreactivity for $\mathrm{pSmad} 3$ in the inner retina cell nuclei with preference to the ganglion cell layer, whereas in the retina of the $S \mathrm{mad} 7^{\Delta \mathrm{co}}$ littermate, $\mathrm{pSmad} 3 \mathrm{immu}$ noreactivity was remarkably more intense and was observed in the inner and outer plexiform layers. $\boldsymbol{E}$, Quantification of TUNEL-labeled cells. The total number of labeled cells was counted atE16.5, P7, and $\mathrm{P} 10$ and was normalized to the area of the retina (mean $\pm \mathrm{SEM}, n \geq 6,{ }^{* *} p=0.0035$ atE16.5, ${ }^{*} p=$ $0.0279 \mathrm{atP7},{ }^{*} p=0.0204$ atP10).F, Cross sections through opticnerves (PPD stain) of a 6-month-old control mouse and its $S \mathrm{mad} 7^{\Delta \circ c}$ littermate. Semithin sections, $1 \mu \mathrm{m}$ thick.
A

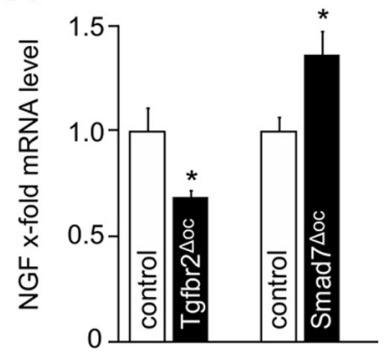

B
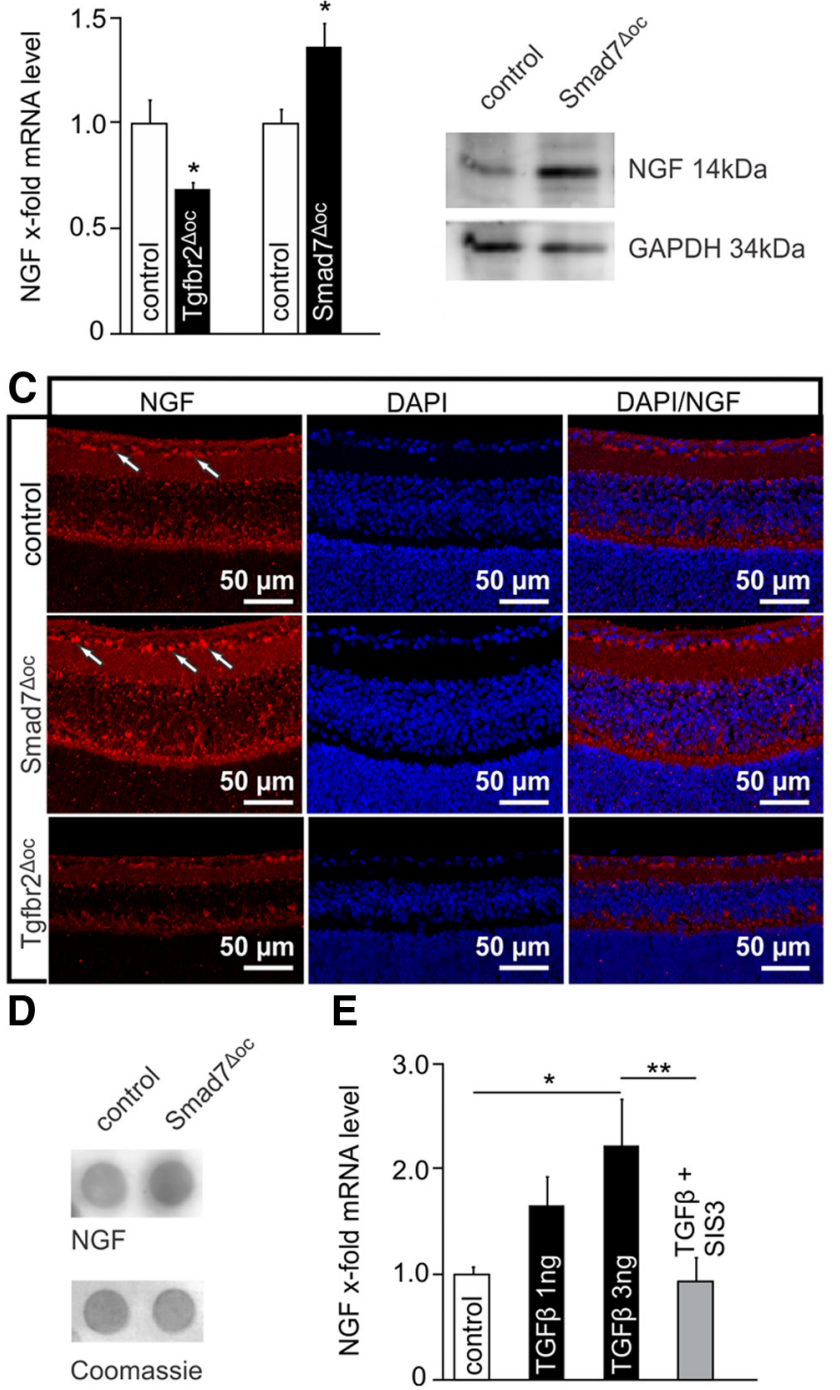

Figure 10. The expression of NGF was modulated by TGF- $\beta$ signaling in the mouse retina. $\boldsymbol{A}$, Quantitative real-time RT-PCR of Ngf mRNA in $T g f b r 2^{\Delta o c}$ and Smad7 ${ }^{\Delta o c}$-deficient mice and control littermates (mean \pm SEM, $n \geq 5,{ }^{*} p=0.0214\left(\operatorname{Tgfbr}^{\Delta o c}\right)^{*} p=0.0366\left(\operatorname{Smad}^{\Delta o \mathrm{o}}\right)$ ). Expression was normalized to Gapdh. $\boldsymbol{B}$, Western blot analysis of NGF in retinal proteins of a $\mathrm{Smad}^{\mathrm{Doc}}$ mouse and its control littermate. GAPDH was used as the loading control. C, NGF immunoreactivity (red) in the retina of control, $\mathrm{Smad}^{\Delta \mathrm{oc}}$ and $\mathrm{Tgfbr}^{2 \mathrm{\Delta oc}}$ mice at P10. In the retina of the $S \mathrm{mad} 77^{\mathrm{Doc}}$ mouse, NGF immunoreactivity was considerably stronger with distinct preference for the perikarya (arrows) in the ganglion cell layer, while labeling of the perikarya in the ganglion cell layer was rarely observed in the Tgfbr $2^{\Delta o c}$ mouse. D, Dot blot analysis of NGF in the retinal proteins of a $S \mathrm{mad} 7^{\Delta \circ C}$ mouse and its control littermate. Coomassie blue was used as the loading control. $\boldsymbol{E}$, Quantitative real-time RT-PCR of NGF mRNA in the RNA isolated from RGC -5 cells treated with TGF- $\beta 2$ ( 1 and $3 \mathrm{ng}$ ) alone or and in combination with SIS3 $(1 \mu \mathrm{M}+3$ ng TGF- $\beta 2$ ), an inhibitor of Smad3 phosphorylation (mean \pm SEM, $n \geq 4,{ }^{*} p=0.0119$ ( $3 \mathrm{ng}$ TGF- $\beta 2),{ }^{* *} p=0.0059$ (SIS3 + TGF- $\left.\left.\beta 2\right)\right)$. Expression was normalized to Gapdh.

ingly, when the RNA from the retinae of P10 Smad $7^{\Delta o c}$ pups was analyzed, the $N g f$ mRNA level was significantly higher ( $p=$ 0.037 ) compared with the control littermates (Fig. 10A). We next investigated if the changes in transcription also resulted in changes of the amount of translated NGF. By Western blot analysis for NGF in retinal proteins from P10 Smad $7^{\Delta o c}$ pups, we observed a distinct band at the expected molecular weight of 14 $\mathrm{kDa}$, which was more intense than in the control littermates (Fig. $10 B)$. We then performed immunohistochemistry to observe immunoreactivity for NGF in the inner retina with distinct prefer- 
ence for perikarya in the ganglion cell layer (Fig. 10C). In the retinae of $S m a d 7^{\Delta o c}$ mice, the immunoreactivity was considerably stronger, while labeling of perikarya in the ganglion cell layer was rarely observed in $T g f b r 2^{\Delta o c}$ mice. Using dot blot analysis to measure via densitometry the relative amount of NGF in retinae of P10 Smad7 $7^{\Delta o c}$ pups (Fig. 10D), we observed a significant increase in the level of NGF compared with the control littermates ( $1.77 \pm 0.32$ vs $1 \pm 0.05, p=0.027, n \geq 5$ ). In contrast, the retinae of P10 Tgfbr $2^{\Delta o c}$ pups showed a significantly lower amount of NGF compared with their control littermates (0.46 \pm 0.043 vs $1 \pm 0.23, p=0.043, n=6$ ). Finally, we treated cultures from the RGC- 5 cell line that displays mouse retinal progenitor cell characteristics with recombinant TGF- $\beta 2$. RGC- 5 cells were first treated with staurosporine to induce a differentiated phenotype (Sippl et al., 2011). When TGF- $\beta 2$ was added at a concentration of $3 \mathrm{ng} / \mathrm{ml}$, we observed a significant increase $(p=0.012)$ in the levels of NGF mRNA, which was blocked completely ( $p=$ 0.006) upon inhibiting TGF- $\beta$ signaling with SIS3 (Fig. 10E).

\section{Discussion}

We conclude that TGF- $\beta$ signaling protects retinal neurons from developmental programmed cell death, an effect that involves diminished phosphorylation of Smad3 and neurotrophic activities of NGF. This conclusion rests upon (1) the generation of mutant $T g f b r 2^{\Delta o c}$ mice with conditional deletion of T $\beta$ RII in cells derived from the inner layer of the optic cup resulting in diminished phosphorylation of retinal Smad3, (2) the discovery of a substantial increase in apoptotic cell death both during postnatal retinal synaptogenesis and embryonic progenitor cell proliferation of Tgfbr2 ${ }^{\Delta o c}$ mice, (3) the finding that adult $T g f b r 2^{\Delta o c}$ mice show a pronounced loss of retinal ganglion cells and neurons in the INL and associated functional deficits, (4) the observation of a protective effect of TGF- $\beta 2$ on the survival of cultured retinal ganglion cells derived from mouse pups, (5) the discovery of a decrease in apoptotic cells during developmental cell death in $S m a d 7^{\Delta o c}$ mice with an increase in phosphorylated Smad3, (6) the detection of a higher number of retinal ganglion cells in $S m a d 7^{\Delta o c}$ mice, and (7) the presence of significantly lower amounts of NFG and its mRNA in Tgfbr ${ }^{\Delta o c}$ mouse pups and of higher amounts of NFG and its mRNA in Smad $7^{\Delta o c}$ pups.

For direct molecular targeting of T $\beta$ RII and Smad7 in retinal neurons, we chose $\alpha$-Cre transgenic mice because Crerecombinase is active in optic cup-derived cells of the animals after E11, a period when developmental programmed cell death of retinal neurons begins (Farah, 2004). We carefully characterized the recombination and the deletion of Tbr2, resulting in $\mathrm{T} \beta \mathrm{RII}$ deficiency and diminished pSmad 3 activity (or its enhanced activity upon Smad7 deficiency) homogenously throughout the entire (central and peripheral) retina. Based on reporter gene assays, several authors have argued that less Cre activity occurs in the central retina of $\alpha$-Cre mice (Marquardt et al., 2001), a finding that is not supported by our analysis of direct target genes. A possible explanation for this discrepancy is the well known tendency of reporter genes to have variegated gene expression, which may result in diminished activity in older cells (Montoliu et al., 2000), or the fact that reporter gene assays depend on enzymatic activity, which is clearly under the influence of physical factors such as the duration of fixation, the penetration of fixative, and the preservation of enzyme in poorly fixed tissues (Ma et al., 2002; Takahashi et al., 2003). These factors may easily differ between central and peripheral parts of the retina, especially when whole embryos are stained.
During the development of the mouse retina, intense expression of mRNA for TGF- $\beta 2$ was observed at E14.5-E16.5 in the progenitor cells of the distal retina and the anterior lens epithelium (Millan et al., 1991). Immunostaining for TGF- $\beta 2$ in retinal ganglion cells and neurons of the INL was observed in E18.5 mouse embryos (Ma et al., 2007). Programmed cell death is detectable in the mouse retina from E12.5 to $\sim 3$ weeks after birth (Young, 1984; Farah and Easter, 2005), and it appears reasonable to assume that during most of this period, retinal TGF- $\beta$ signaling is available at high activity levels to attenuate the apoptosis of retinal progenitor cells and of more differentiated retinal neurons in an autocrine- or paracrine-dependent manner.

Our findings obtained by direct and specific molecular targeting in the living mouse eye substantially differ from the findings reported for the developing avian retina (Dünker et al., 2001) or in mouse retinal explant cultures (Duenker et al., 2005). In both models, a promoting effect of TGF- $\beta$-signaling on the programmed cell death of retinal neurons was observed either by the neutralization of TGF- $\beta$ signaling in the avian embryo with specific antibodies against all three TGF- $\beta$ isoforms or the direct treatment of explanted retinae with TGF- $\beta$. Several but not necessarily mutually exclusive possible explanations for the divergent findings exist. First, during eye development, TGF- $\beta$ signaling may have more functions than only modulating programmed cell death. As a result, the neutralization of all TGF- $\beta$ isoforms or the increase in the local amounts of available TGF- $\beta$ may initiate events in cells other than neuronal progenitors, e.g., microglia, that indirectly affect programmed cell death. Second, the neutralizing antibodies against TGF- $\beta$ isoforms react with other signaling factors. Third, in explant cultures containing injured axotomized retinal ganglion cells, TGF- $\beta$ signaling may initiate cellular events that substantially differ from the events that occur during the development of the intact eye. Interestingly, our observation of increased neuronal programmed cell death in $T g f b r 2^{\Delta o c}$ mice is quite comparable to the occurrences observed in Tgfb1 $1^{-1-}$ mice that lack TGF- $\beta 1$ (Brionne et al., 2003). $T g f b 1^{-1-}$ animals show a significant increase in the number of TUNEL-labeled neurons in the neocortex at P1, a time when programmed cell death associated with synaptogenesis occurs (Naruse and Keino, 1995).

While the average number of optic nerve axons observed in control animals is well within the range reported for other mouse strains, the number witnessed in Tgfbr2 ${ }^{\Delta o c}$ animals is comparable to the number reported for experimental mouse models of retinal ganglion cell degeneration that mimic glaucoma (Howell et al., 2007; Junglas et al., 2012), a neurodegenerative disease of retinal ganglion cells (Kwon et al., 2009). We, therefore, assume that the reduction in retinal ganglion cells is sufficient to cause functional deficits, a hypothesis that we confirmed by ERG analysis. The significant differences in single flash cone response amplitudes and implicit times, which we observed in Tgfbr $2^{\Delta o c}$ animals, are likely to reflect changes in the contribution of the inner retinal components to the response to bright flashes. Optic nerve transection and pharmacological studies in rats and mice proved the contribution of retinal ganglion cells to the positive and negative components of the dark-adapted STR. With brighter flashes, the responses receive little influence from retinal ganglion cells (Saszik et al., 2002; Bui and Fortune, 2004; Alarcón-Martínez et al., 2010). The loss of retinal ganglion cells resulted in a reduction of b-wave amplitude and an elevation of the STR component. The absence of differences in the scotopic ERGs and a typical waveform change of the STR, as observed in our study, are thus strongly consistent with a reduction of proximal retinal function 
such as the loss of retinal ganglion cells in $T g f b r 2^{\Delta o c}$ animals that is sufficient to affect their function.

TGF- $\beta$ signaling may protect retinal neurons not only from developmental programmed cell death but also from apoptotic cell death in the adult retina. In support of this hypothesis are recent findings reported by Walshe et al. (2009) who neutralized TGF- $\beta$ in the adult mouse eye via the expression of soluble endoglin, a TGF- $\beta$ inhibitor. In the course of these studies, apoptosis of retinal ganglion cells was observed in addition to functional deficits detected by ERG. Moreover, in the RGC- 5 cell line, which is derived from retinal progenitors (Van Bergen et al., 2009; Sippl et al., 2011), TGF- $\beta 1$ decreased apoptosis (Walshe et al., 2011), similarly to the action of TGF- $\beta 2$ on retinal ganglion cells in dissociated retinal cultures in our study.

Overall, a neuroprotective activity of TGF- $\beta$ signaling for retinal neurons is comparable to the neuroprotective activities of TGF- $\beta$ s that were reported for multiple types of neurons throughout the CNS such as in the striatum (Ma et al., 2008), spinal cord (Park et al., 2008), substantia nigra (Roussa et al., 2009), or hippocampus (Zhu et al., 2004). Our results indicate that the protective effects of TGF- $\beta$ signaling on developmental programmed cell death may involve the Smad pathway, including the phosphorylation of $S \operatorname{mad} 3$, which decreases in the retina upon conditional inactivation of T $\beta$ RII. In contrast, conditional deletion of the negative regulator of TGF- $\beta$ signaling, Smad7 (Park, 2005; Yan et al., 2009), increases the levels of pSmad3, while reducing the number of apoptotic cells in the developing retina.

Our data also indicate that the neuroprotective effects of TGF- $\beta$ on developmental programmed cell death may be mediated through NGF, which is induced by TGF- $\beta$, an effect quite comparable to the effects observed in other cell types (Haas et al., 2009). In contrast to the avian retina (González-Hoyuela et al., 2001), the neuroprotective TrkA receptor of NGF is widely expressed in proliferating retinal progenitor cells of the embryonic mouse eye at E15 (Harada et al., 2006). In this period, the precursors of retinal ganglion cells and neurons in the INL proliferate (Sidman, 1961; Farah and Easter, 2005), which are reduced in number in the adult Tgfbr $2^{\Delta o c}$ mice in our study. TrkA is also expressed in differentiated retinal ganglion cells (Lebrun-Julien et al., 2009) and may mediate the protective effects of TGF- $\beta$ / NGF on the apoptosis of retinal ganglion cells in mouse pups during synaptogenesis.

\section{References}

Alarcón-Martínez L, Avilés-Trigueros M, Galindo-Romero C, ValienteSoriano J, Agudo-Barriuso M, Villa Pde L, Villegas-Pérez MP, Vidal-Sanz M (2010) ERG changes in albino and pigmented mice after optic nerve transection. Vision Res 50:2176-2187. CrossRef Medline

Braunger BM, Ohlmann A, Koch M, Tanimoto N, Volz C, Yang Y, Bösl MR, Cvekl A, Jägle H, Seeliger MW, Tamm ER (2013) Constitutive overexpression of Norrin activates Wnt/beta-catenin and endothelin-2 signaling to protect photoreceptors from light damage. Neurobiol Dis 50:1-12. CrossRef Medline

Brionne TC, Tesseur I, Masliah E, Wyss-Coray T (2003) Loss of TGF-beta 1 leads to increased neuronal cell death and microgliosis in mouse brain. Neuron 40:1133-1145. CrossRef Medline

Bui BV, Fortune B (2004) Ganglion cell contributions to the rat full-field electroretinogram. J Physiol 555:153-173. Medline

Buss RR, Sun W, Oppenheim RW (2006) Adaptive roles of programmed cell death during nervous system development. Annu Rev Neurosci 29:1-35. CrossRef Medline

Chytil A, Magnuson MA, Wright CV, Moses HL (2002) Conditional inactivation of the TGF-beta type II receptor using Cre:Lox. Genesis 32:73-75. CrossRef Medline

Duenker N, Valenciano AI, Franke A, Hernández-Sánchez C, Dressel R, Beh- rendt M, De Pablo F, Krieglstein K, de la Rosa EJ (2005) Balance of pro-apoptotic transforming growth factor-beta and anti-apoptotic insulin effects in the control of cell death in the postnatal mouse retina. Eur J Neurosci 22:28-38. CrossRef Medline

Dünker N, Krieglstein K (2003) Reduced programmed cell death in the retina and defects in lens and cornea of Tgfbeta2 $(-/-)$ Tgfbeta3 $(-/-)$ double-deficient mice. Cell Tissue Res 313:1-10. CrossRef Medline

Dünker N, Schuster N, Krieglstein K (2001) TGF-beta modulates programmed cell death in the retina of the developing chick embryo. Development 128:1933-1942. Medline

Farah MH (2004) Cumulative labeling of embryonic mouse neural retina with bromodeoxyuridine supplied by an osmotic minipump. J Neurosci Methods 134:169-178. CrossRef Medline

Farah MH, Easter SS Jr (2005) Cell birth and death in the mouse retinal ganglion cell layer. J Comp Neurol 489:120-134. CrossRef Medline

Frade JM, Barde YA (1998a) Microglia-derived nerve growth factor causes cell death in the developing retina. Neuron 20:35-41. CrossRef Medline

Frade JM, Barde YA (1998b) Nerve growth factor: two receptors, multiple functions. Bioessays 20:137-145. CrossRef Medline

Frade JM, Barde YA (1999) Genetic evidence for cell death mediated by nerve growth factor and the neurotrophin receptor p75 in the developing mouse retina and spinal cord. Development 126:683-690. Medline

González-Hoyuela M, Barbas JA, Rodríguez-Tébar A (2001) The autoregulation of retinal ganglion cell number. Development 128:117-124. Medline

Haas SL, Fitzner B, Jaster R, Wiercinska E, Gaitantzi H, Jesenowski R, Löhr JM, Singer MV, Dooley S, Breitkopf K (2009) Transforming growth factor-beta induces nerve growth factor expression in pancreatic stellate cells by activation of the ALK-5 pathway. Growth Factors 27:289-299. CrossRef Medline

Hao W, Wenzel A, Obin MS, Chen CK, Brill E, Krasnoperova NV, EversoleCire P, Kleyner Y, Taylor A, Simon MI, Grimm C, Remé CE, Lem J (2002) Evidence for two apoptotic pathways in light-induced retinal degeneration. Nat Genet 32:254-260. CrossRef Medline

Harada C, Harada T, Nakamura K, Sakai Y, Tanaka K, Parada LF (2006) Effect of p75NTR on the regulation of naturally occurring cell death and retinal ganglion cell number in the mouse eye. Dev Biol 290:57-65. CrossRef Medline

Haverkamp S, Wässle H (2000) Immunocytochemical analysis of the mouse retina. J Comp Neurol 424:1-23. CrossRef Medline

Howell GR, Libby RT, Jakobs TC, Smith RS, Phalan FC, Barter JW, Barbay JM, Marchant JK, Mahesh N, Porciatti V, Whitmore AV, Masland RH, John SW (2007) Axons of retinal ganglion cells are insulted in the optic nerve early in DBA/2J glaucoma. J Cell Biol 179:1523-1537. CrossRef Medline

Ito Y, Yeo JY, Chytil A, Han J, Bringas P Jr, Nakajima A, Shuler CF, Moses HL, Chai Y (2003) Conditional inactivation of Tgfbr2 in cranial neural crest causes cleft palate and calvaria defects. Development 130:5269-5280. CrossRef Medline

Junglas B, Kuespert S, Seleem AA, Struller T, Ullmann S, Bösl M, Bosserhoff A, Köstler J, Wagner R, Tamm ER, Fuchshofer R (2012) Connective tissue growth factor causes glaucoma by modifying the actin cytoskeleton of the trabecular meshwork. Am J Pathol 180:2386-2403. CrossRef Medline

Karnovsky MJ (1965) A formaldehyde-glutaraldehyde fixative of high osmolality for use in electron-microscopy. J Cell Biol 27:137-138.

Kleiter I, Song J, Lukas D, Hasan M, Neumann B, Croxford AL, Pedré X, Hövelmeyer N, Yogev N, Mildner A, Prinz M, Wiese E, Reifenberg K, Bittner S, Wiendl H, Steinman L, Becker C, Bogdahn U, Neurath MF, Steinbrecher A, et al. (2010) Smad7 in T cells drives T helper 1 responses in multiple sclerosis and experimental autoimmune encephalomyelitis. Brain 133:1067-1081. CrossRef Medline

Kritzenberger M, Junglas B, Framme C, Helbig H, Gabel VP, Fuchshofer R, Tamm ER, Hillenkamp J (2011) Different collagen types define two types of idiopathic epiretinal membranes. Histopathology 58:953-965. CrossRef Medline

Kroeber M, Davis N, Holzmann S, Kritzenberger M, Shelah-Goraly M, Ofri R, Ashery-Padan R, Tamm ER (2010) Reduced expression of Pax6 in lens and cornea of mutant mice leads to failure of chamber angle development and juvenile glaucoma. Hum Mol Genet 19:3332-3342. CrossRef Medline

Kwon YH, Fingert JH, Kuehn MH, Alward WL (2009) Primary open-angle glaucoma. N Engl J Med 360:1113-1124. CrossRef Medline 
Lebrun-Julien F, Morquette B, Douillette A, Saragovi HU, Di Polo A (2009) Inhibition of p75(NTR) in glia potentiates TrkA-mediated survival of injured retinal ganglion cells. Mol Cell Neurosci 40:410-420. CrossRef Medline

Ma L, Cantrup R, Varrault A, Colak D, Klenin N, Götz M, McFarlane S, Journot L, Schuurmans C (2007) Zac1 functions through TGFbetaII to negatively regulate cell number in the developing retina. Neural Dev 2:11. CrossRef Medline

Ma M, Ma Y, Yi X, Guo R, Zhu W, Fan X, Xu G, Frey WH 2nd, Liu X (2008) Intranasal delivery of transforming growth factor-betal in mice after stroke reduces infarct volume and increases neurogenesis in the subventricular zone. BMC Neurosci 9:117. CrossRef Medline

Ma W, Rogers K, Zbar B, Schmidt L (2002) Effects of different fixatives on beta-galactosidase activity. J Histochem Cytochem 50:1421-1424. CrossRef Medline

Marquardt T, Ashery-Padan R, Andrejewski N, Scardigli R, Guillemot F, Gruss P (2001) Pax6 is required for the multipotent state of retinal progenitor cells. Cell 105:43-55. CrossRef Medline

Millan FA, Denhez F, Kondaiah P, Akhurst RJ (1991) Embryonic gene expression patterns of TGF beta 1, beta 2 and beta 3 suggest different developmental functions in vivo. Development 111:131-143. Medline

Montoliu L, Chávez S, Vidal M (2000) Variegation associated with lacZ in transgenic animals: a warning note. Transgenic Res 9:237-239. CrossRef Medline

Naruse I, Keino H (1995) Apoptosis in the developing CNS. Prog Neurobiol 47:135-155. CrossRef Medline

Nykjaer A, Willnow TE, Petersen CM (2005) p75NTR-live or let die. Curr Opin Neurobiol 15:49-57. CrossRef Medline

Oppenheim RW (1991) Cell death during development of the nervous system. Annu Rev Neurosci 14:453-501. CrossRef Medline

Park SH (2005) Fine tuning and cross-talking of TGF-beta signal by inhibitory Smads. J Biochem Mol Biol 38:9-16. CrossRef Medline

Park SM, Jung JS, Jang MS, Kang KS, Kang SK (2008) Transforming growth factor-betal regulates the fate of cultured spinal cord-derived neural progenitor cells. Cell Prolif 41:248-264. CrossRef Medline

Richardson KC, Jarret L, Finke EH (1960) Embedding in epoxy resins for ultrathin sectioning in electron microscopy. Stain Technol 35:313-323. Medline

Roussa E, von Bohlen und Halbach O, Krieglstein K (2009) TGF-beta in dopamine neuron development, maintenance and neuroprotection. Adv Exp Med Biol 651:81-90. CrossRef Medline

Saszik SM, Robson JG, Frishman LJ (2002) The scotopic threshold re- sponse of the dark-adapted electroretinogram of the mouse. J Physiol 543:899-916. CrossRef Medline

Seitz R, Hackl S, Seibuchner T, Tamm ER, Ohlmann A (2010) Norrin mediates neuroprotective effects on retinal ganglion cells via activation of the Wnt/beta-catenin signaling pathway and the induction of neuroprotective growth factors in Müller cells. J Neurosci 30:5998-6010. CrossRef Medline

Sidman RC (1961) Histogenesis of mouse retina studied with thymidineH3. In: The structure of the eye (Smelser GK, ed), pp 487-506. New York: Academic.

Sippl C, Bosserhoff AK, Fischer D, Tamm ER (2011) Depletion of optineurin in RGC-5 cells derived from retinal neurons causes apoptosis and reduces the secretion of neurotrophins. Exp Eye Res 93:669-680. CrossRef Medline

Takahashi M, Hakamata Y, Takeuchi K, Kobayashi E (2003) Effects of different fixatives on beta-galactosidase activity. J Histochem Cytochem 51: 553-554. CrossRef Medline

Van Bergen NJ, Wood JP, Chidlow G, Trounce IA, Casson RJ, Ju WK, Weinreb RN, Crowston JG (2009) Recharacterization of the RGC-5 retinal ganglion cell line. Invest Ophthalmol Vis Sci 50:4267-4272. CrossRef Medline

Walshe TE, Saint-Geniez M, Maharaj AS, Sekiyama E, Maldonado AE, D'Amore PA (2009) TGF-beta is required for vascular barrier function, endothelial survival and homeostasis of the adult microvasculature. PLoS One 4:e5149. CrossRef Medline

Walshe TE, Leach LL, D'Amore PA (2011) TGF-beta signaling is required for maintenance of retinal ganglion cell differentiation and survival. Neuroscience 189:123-131. CrossRef Medline

Wickham H (2009) Ggplot2: elegant graphics for data analysis. New York: Springer.

Yan X, Liu Z, Chen Y (2009) Regulation of TGF-beta signaling by Smad7. Acta Biochim Biophys Sin 41:263-272. CrossRef Medline

Yeo W, Gautier J (2004) Early neural cell death: dying to become neurons. Dev Biol 274:233-244. CrossRef Medline

Young RW (1984) Cell death during differentiation of the retina in the mouse. J Comp Neurol 229:362-373. CrossRef Medline

Zhu Y, Culmsee C, Klumpp S, Krieglstein J (2004) Neuroprotection by transforming growth factor-betal involves activation of nuclear factorkappaB through phosphatidylinositol-3-OH kinase/Akt and mitogenactivated protein kinase-extracellular-signal regulated kinase 1,2 signaling pathways. Neuroscience 123:897-906. CrossRef Medline 